\title{
De Cobras e Lagartos: as tangas marajoaras
}

André Prous*

A. Pessoa Lima**

PROUS, A.; LIMA, A.P. De Cobras e Lagartos: as tangas marajoaras. R. Museu Arq.

Etn., São Paulo, n. 21, p. 231-263, 2011.

Resumo: As tangas em cerâmica são emblemáticas da Fase Marajoara. Estudando mais de 140 exemplares decorados e dezenas de peças simples, identificamos as regras que regem a organização da decoração, assim como as fórmulas gráficas utilizadas em cada registro decorativo. Mostramos que os desenhos do campo decorativo principal são figurações altamente estilizadas de rostos, representados através do sistema de kennings. A coincidência entre tipo morfológico, organização do espaço pictural, recursos gráficos e elementos figurativos permite inserir as tangas em sete grupos tipológicos, cujo significado (cronológico, regional, social) é discutido dentro do contexto marajoara. Apresentamos as marcas de utilização, enquanto nossos colaboradores realizam réplicas em cerâmica e utilizam-nas par verificar sua adequação à anatomia feminina.

Palavras-chave: Tangas de cerâmica - Fase Marajoara - Arqueologia amazônica - Pintura em cerâmica.

\section{Introdução}

$\mathrm{D}$ esde o final do século XIX, as tangas em cerâmica encontradas nos tesos da ilha de Marajó atraíram a atenção dos primeiros estudiosos da arqueologia amazônica. A tal ponto que uma delas era reproduzida em 1871 na revista American Naturalist e que, no Brasil, o primeiro volume dos

$\left.{ }^{*}\right)$ Universidade Federal de Minas Gerais. CNPq; Missão Arqueológica Franco-Brasileira de Minas Gerais. <aprous80@gmail.com>

$\left.{ }^{(* *}\right)$ Setor de Arqueologia pré-histórica da UFMG, Mestrando na UFPA. <lima.angelo@gmail.com>
Archivos do Museu Nacional já apresentava um artigo sobre estes artefatos (Hartt 1871, 1876). (Fig. 1) ${ }^{1}$

Desde então, as tangas Marajoara são mencionadas em todas as publicações que tratam da arqueologia da foz do rio Amazonas ou da arte pré-histórica brasileira em geral. Esses trabalhos, no entanto, não

(1) As ilustrações (fotografias e desenhos) são dos autores. O desenho da Fig. 15 é reproduzido de Schaan 2001; o da Fig. 7 é reproduzido de Ramos 1932. As peças que ilustram as pranchas estão conservadas nas coleções do MAE/USP, do Museu Paraense Emílio Goeldi, do Museu Nacional (desenhos), do Museu Universitário da UFSC, do Museu Pe. Galo de Cachoeira do Arari e do Museu do Forte. 


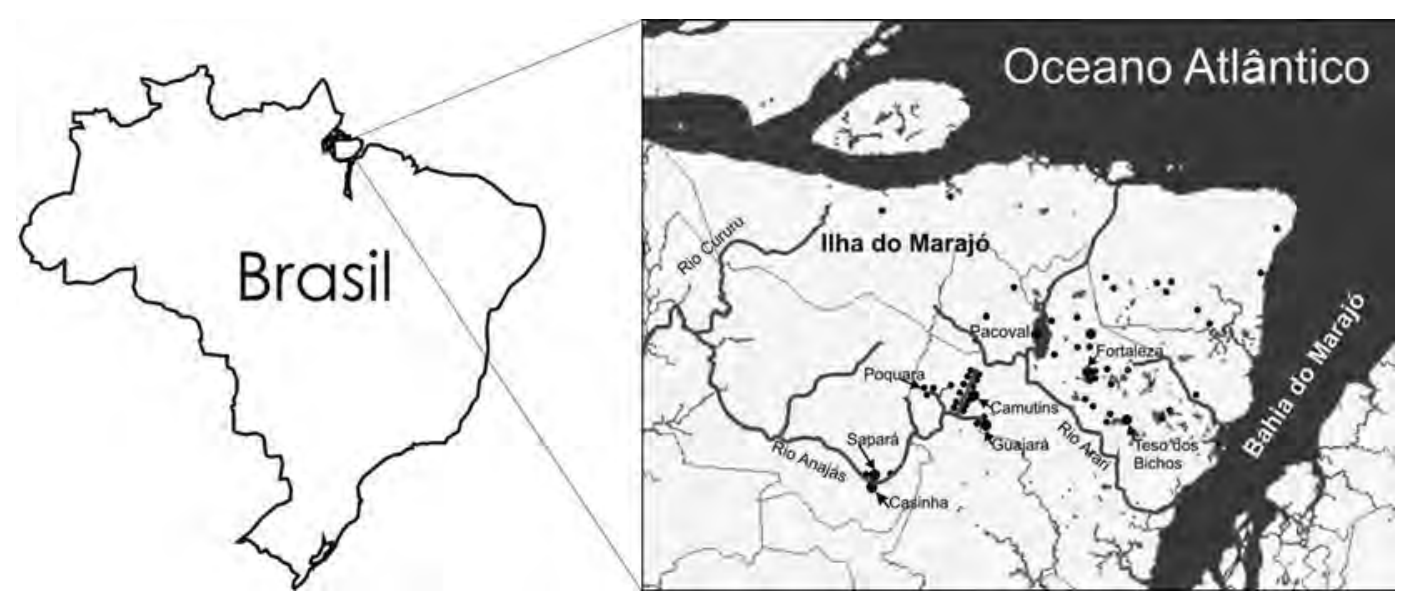

Fig. 1. Mapa dos sítios da Fase Marajoara.

focalizaram essencialmente as tangas (Barata, 1952; Meggers e Evans 1957; Barbosa Rodrigues 1892; Costa 1939; Herança 1984), ou apresentaram apenas uma amostra reduzida (Hartt 1876; Mordini 1929; Palmatary 1950), mesmo quando tratavam de interpretar esses artefatos (Schaan 2003). Os autores pouco se interessaram pelos grafismos desenhados no campo decorativo principal; foram simplesmente qualificados como geométricos - enquanto, desde o primeiro olhar, tivemos a certeza de que a maioria das peças apresentava representações da figura humana. Desta forma, parecia haver espaço para um trabalho mais abrangente que pudesse se sustentar a partir de um universo maior, quantitativamente representativo. Uma oportunidade de consultar a coleção do Museu Paraense Emílio Goeldi ressuscitou um antigo projeto nosso de abordar a iconografia marajoara. Iniciamos então um levantamento geral das tangas depositadas em Museus e coleções, através de desenhos feitos à mão, fotografias e observações sistemáticas. Esta pesquisa foi completada por uma revisão (provavelmente incompleta) da bibliografia e de sites da IN. TERNET - dois deles, inclusive, destinados a vender peças. Desta forma, o presente ensaio se apoia num universo de 149 exemplares pintados, 77 fragmentos com desenhos diagnósticos e 94 tangas monocromas (incluindo algumas falsificações e imitações).

\section{Revisão bibliográfica e levantamento de coleções}

O. Derby e seu colega Bechley, visitando o teso de Pacoval nos anos de 1870, encontraram uma tanga de cerâmica pintada, que foi depositada no Museu de Etnografia Comparada do Peabody Museum (Cambridge, Mass.). Logo depois, C. Hartt (1871) publicou desenhos legendados deste tipo de peças. Mordini (1929 e 1934), comentando uma dezena desses artefatos proveniente das escavações realizadas pelo colecionador C. E. de Oliveira, notou a recorrência do motivo retangular / triangular da banda decorada superior das tangas provenientes de Pacoval, e sua ausência nas tangas encontradas no teso do Severino. Também salientou outra diferença entre a produção dos dois sítios, considerando a arte de Pacoval mais arcaica (tanto na qualidade da queima quanto na realização dos desenhos) que aquela do Severino. Interpretou o desenho central de uma das tangas deste sítio como uma possível representação esquemática de corpo humano - de fato, a peça mencionada pode sugerir uma pessoa com os membros escolhidos. Salientou também a oposição morfológica entre as tangas policromas (mais pesadas e com maior cava) e aquelas apenas cobertas por um engobo vermelho. Em função de grau de desgaste dos orifícios de suspensão, B. Meggers e C. Evans (1957) afirmam que as primeiras seriam mais usadas no cotidiano e as outras, 
ritualmente. Algumas linhas adiante, os mesmos pesquisadores sugerem - de forma algo contraditória - que a variação de frequência relativa dessas duas categorias seria de ordem cronológica. Estes autores são os únicos a comentar a face interna dessas peças de vestuário, verificando que as vermelhas apresentam engobo interno e externo, enquanto as policromas não apresentam engobo na parte central da face interna. D. Pahl Schaan (2001), por sua vez, interpretou o motivo superior como representação de genitália feminina e, a partir da sugestão de um zoólogo, considerou os motivos da segunda banda imediatamente abaixo da primeira, como sendo representações esquematizadas de desenhos de peles de cobra. D. Schaan, no entanto, se interessou particularmente pelas tangas, numa ótica de "arqueologia de gênero". Considera que as tangas de cerâmica seriam reservadas a mulheres da elite - por serem essas encontradas essencialmente em tesos maiores, supostamente habitados pelos dirigentes da sociedade Marajoara. Pela associação preferencial das tangas monocromáticas com as urnas funerárias e considerando que sua curvatura seria menor, esta arqueóloga supõe que pertenceriam a mulheres adultas e casadas, enquanto as menores, policromas e de forte curvatura, seriam usadas por meninas durante a puberdade.

Várias coleções comportam tangas - inteiras ou fragmentos - no Brasil e no exterior, parte da quais pudemos estudar diretamente.

A maior coleção parece ser aquela do extinto Banco Santos. Atualmente depositada no MAE-USP, comporta 53 peças inteiras desenhadas e dois fragmentos, assim como 59 apenas engobadas de vermelho (das quais algumas parecem ser falsificações). Segundo Barreto (2009), as peças seriam provenientes do rio Anajás, no oeste da região ocupada pelos tesos marajoara; esta coleção será daqui para frente designada pela sigla MAE/BS. Analisamos as coleções do Museu do Marajó em Cachoeira do Arari (oito tangas pintadas e numerosos fragmentos), cujas peças seriam provenientes, sobretudo, da região de São Sebastião do Arari - na parte central do domínio marajoara. Visitamos as exposições do Forte do Presépio e do Museu das Gemas em Belém (nove tangas pintadas e várias peças monocromas); a maioria estando exposta ao público, desenhamos e fotografamos a face visível e pudemos consultar suas fichas, mas não as pudemos manusear.

Não estudamos a coleção do Museu Nacional, que vem sendo analisada por T. Andrade Lima. Da coleção do Museu Paraense Emilio Goeldi, vimos 14 tangas policromas e 13 apenas engobadas. Através da bibliografia, pudemos observar os desenhos das tangas do Peabody Museum, do American Museum of Natural History, da Heyde Foundation, do National Museum of Natural History, de algumas peças do Museu Nacional do Rio de Janeiro (Hartt 1876); H. Torres 1929; D. Schaan 2001), em sua maior parte provenientes de Pacoval do Arari. B. Meggers e C. Evans (1957) publicaram duas peças policromas e as três vermelhas provenientes das suas escavações em Camutin; H. Palmatary (1950) ilustra oito peças policromas (além de dois fragmentos) e uma vermelha - então conservadas na coleção Oliveira (Recife) - além de duas peças do Museu Etnográfico de Estocolmo. Em sua dissertação de Mestrado, J. Troufflard (2010) apresentou duas peças pintadas conservadas no Museu Nacional de Etnologia de Lisboa, e três do Museu Dr. Rocha, de Figueira da Foz. D. Schaan forneceu-nos generosamente sua documentação fotográfica pessoal, da qual constavam 17 peças que ainda desconhecíamos e 16 fragmentos de Camutins. S. Rostain nos brindou com o desenho de sua autoria da tanga conservada no Museu Barbier-Mueller, de Genebra. Na INTERNET, finalmente, conseguimos consultar as fotografias de outras três tangas policromas e de uma engobada, sem indicação da coleção de origem. Daqui para frente, as peças provenientes dessas diversas fontes serão designadas pelo número que lhes atribuímos dentro do nosso catálogo próprio.

Pretendemos, em futuro próximo, publicar um catálogo descritivo e ilustrado deste material.

\section{A matéria e a morfologia das tangas}

Não é nosso propósito estudar as características técnicas de fabricação das tangas; apenas registramos que a grande maioria das peças 
fraturadas apresenta indícios de uma queima totalmente oxidante, e uma cor de superfície alaranjada. Pereira de Freitas (2009) realizou uma análise por Fluorescência X das pastas de alguns exemplares conservados no Museu Nacional, verificando que se agrupam em dois conjuntos - mesmo assim, bastante parecidos. Isto não é de se estranhar, na medida em que as argilas são provavelmente todas procedentes dos mesmos alúvios transportados pela correnteza do curso inferior e da foz do rio Amazonas.

Às duas categorias morfológicas já reconhecidas pelos pesquisadores acrescentamos outra, que pudemos observar na coleção depositada no MAE-USP e no Museu de Cachoeira do Arari, sendo que uma peça semelhante aparece também registrada numa prancha de Meggers \& Evans (1957). Compararemos rapidamente estas três formas básicas, considerando tratar-se de formas aparentadas a triângulos, com um lado superior horizontal e dois lados oblíquos direito e esquerdo - simétricos.

Tipo morfológico 1: Congrega quase três quartos das peças com desenhos pintados. Corresponde a peças a grosso modo triangulares, com dimensões menores em relação aos demais tipos. Tem largura entre 11 e $17 \mathrm{~cm}$ (tendo a grande maioria entre 12 e $14 \mathrm{~cm}$ ) e altura entre 8,6 e 13,6 cm ( geralmente entre 9,5 e 12 $\mathrm{cm})$. A relação entre altura e largura é da ordem de 12/14. O lado superior é reto, sendo os vértices laterais rombudos. $\mathrm{O}$ ramo inferior tende a ser mais largo que aquele do tipo 2. Os lados oblíquos apresentam-se suavemente cavados. Quando a peça é colocada numa superfície plana, o ponto mais alto levanta-se acima desta entre 3,5 e $5 \mathrm{~cm}$, o que corresponde a cerca de $1 / 3$ da largura da peça. Trata-se da mais forte curvatura antero-posterior (ou arqueamento) relativa média entre os três tipos. Algumas dessas peças apresentam, em sua parte central, uma discretíssima saliência em calota de esfera, aumentando a capacidade volumétrica do artefato. Os furos de suspensão estão colocados a pouca distância das pontas (um pouco mais de $2 \mathrm{~cm}$ para furos laterais, um pouco mais de $1,5 \mathrm{~cm}$ para o furo inferior.

Tipo morfológico 2: Reúne quase 1/4 das peças com desenhos. A altura destas tangas é a mesma do tipo anterior (entre 9 e $13,5 \mathrm{~cm}$ ), mas os braços laterais são bem mais compridos, terminando quase em ponta cônica alongada. As peças ficam assim com largura maior, geralmente entre 14 e $18 \mathrm{~cm}$ (as exceções medindo entre 12 e 13 , ou entre 19 e pouco mais de $20 \mathrm{~cm}$ ). A relação largura/comprimento é de cerca de $7 / 10$. O raio de curvatura antero-posterior tende a ser um pouco menor que no tipo anterior: deitada, a peça levanta-se raramente mais de 4,2 cm, embora as duas exceções alcancem o maior arqueamento individual entre todas as tangas $(5,2 \mathrm{~cm})$. A relação entre a flecha e a largura é da ordem de $1 / 4$. O lado superior das peças deste tipo morfológico apresenta quase sempre um abaulamento central - discreto, porém perfeitamente visível - enquanto os lados oblíquos apresentam uma reentrância cuja cava costuma ser mais marcada e de curva mais contínua que aquela do tipo anterior. Este abaulamento talvez não seja procurado intencionalmente; poderia apenas decorrer da preparação das "pontas" laterais. Com efeito, estas são arredondadas para apresentar um formato quase cilíndrico, deixando em relevo a parte central que se mantém achatada.

Os furos laterais podem ser bastante distantes das extremidades (até 3,4 cm), provavelmente para diminuir os riscos de quebra das pontas delgadas - acidente muito frequente nas peças deste formato.

Tipo morfológico 3: Muito mais raro, é representado por sete peças de tamanho semelhante, cuja largura e altura são quase equivalentes (11 a $13 \mathrm{~cm}$ de altura e $12 \mathrm{~cm}$ de largura). Os lados praticamente não são cavados e os vértices são 
perfeitamente arredondados. A curvatura antero-posterior é muito variável (entre 2,4 e 4,2 cm). Todas as peças que apresentam esta morfologia ostentam a mesma fórmula decorativa tripartida (descrita adiante).

\section{Variante}

Nota-se que algumas peças apresentam uma morfologia parecida em sua parte superior com aquela das peças do grupo 1, mas com uma altura equivalente à largura; sua cava é pouco pronunciada. Não se trata de um acaso, mas de uma variante significativa, pois estas mesmas tangas apresentam uma organização tripartida do espaço decorativo diferente do que ocorre nos demais artefatos deste grupo1 - sendo semelhante àquela das peças do grupo 3. (Fig. 2).

Algumas características de decoração são correlacionadas à morfologia e à decoração. Por exemplo, as peças de forma 2 apresentam um friso superior estreito, enquanto o mesmo (com a mesma temática) é de largura média nas peças de forma 1; este campo é mais largo ainda nas peças de forma 3 ou com decoração tripartida. O segundo friso, por sua vez, é praticamente ausente - substituído por uma simples linha reforçada na forma 2, enquanto se torna o campo de decoração principal na forma 3, etc. Desde o século XIX, os autores afirmam que as tangas de extremidades pontudas (nossa "forma 2") não apresentariam decoração pintada, recebendo apenas um banho vermelho), enquanto aquelas de forma 1 seriam sempre decoradas com desenhos. $\mathrm{O}$ estudo das diversas coleções mostra, no entanto, que esta oposição não é válida.

As peças de tipo morfológico 3 são, por sua vez, todas policromas - com exceção de uma delas, que pudemos observar apenas a partir de uma ilustração pouco legivel), qualificada de "plain" por Meggers e Evans (1957); talvez esta seja inacabada.

Nota-se que, entre as poucas tangas apenas engobadas de branco depositadas nos Museus Goeldi e do Forte, há tanto exemplares de mor-

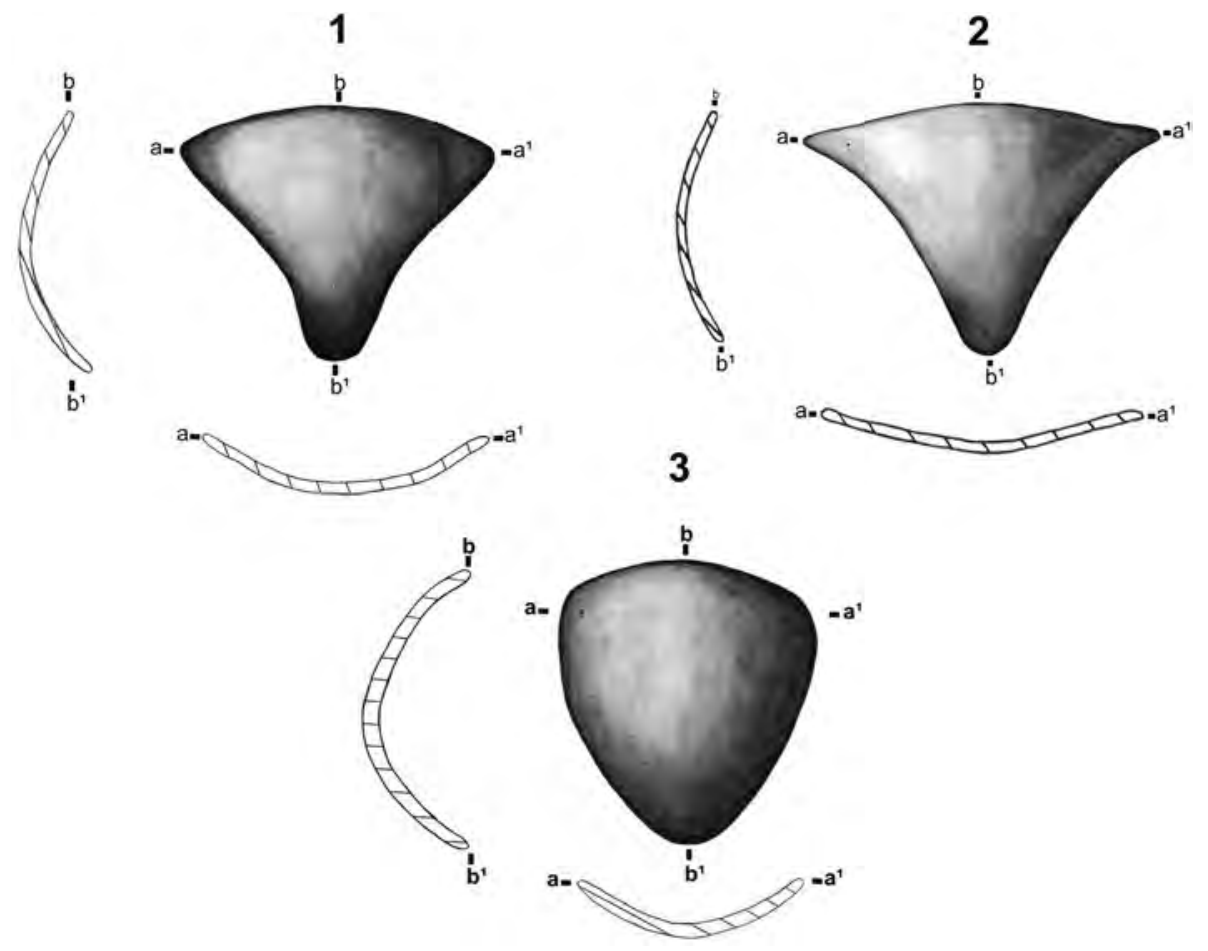

Fig 2. Morfologias das tangas. 
fologia 1 quanto de morfologia 2. Talvez se trate de tangas que eram destinadas a receber desenhos, mas cuja decoração não foi terminada.

\section{O espaço e os elementos gráficos}

\section{O espaço}

A não ser raras exceções, a face externa das tangas pintadas foi dividida pelas artistas (consideraremos a priori - embora sem nenhuma certeza - tratar-se de mulheres; por isto utilizaremos o feminino daqui para diante) em três ou quatro faixas horizontais de largura desigual, delimitadas por linhas horizontais e geralmente separadas uma das outras por um estreito espaço não desenhado.

$\mathrm{O}$ registro superior corresponde à maior largura da peça; costuma ter cerca de 2 centímetros de altura nas peças de forma 1; é muito mais estreito na forma 2 , enquanto é bem mais largo (ocupa quase um quarto da altura dela) nas tangas de forma 3. Neste registro abrem-se os dois furos superiores de suspensão. Apresenta quase sempre um elemento central reproduzido lateralmente em posição inclinada, de forma simétrica.

O segundo registro, que denominamos médio, é decorado por um friso. Nas peças de morfologia 1 , este é o mais estreito de todos os campos decorativos; nas peças de forma 2, acaba sendo reduzido a uma simples linha reforçada de separação. Nas peças de morfologia 3, pelo contrário, desloca-se para a parte central da tanga, torna-se muito largo e o registro mais vistoso.

O registro principal ocupa a parte central da peça; é a faixa decorada mais alta de todas e que ocupa a maior superfície, sendo mais alta - embora menos larga - que as duas anteriores. Este registro costuma apresentar um motivo principal inserido num retângulo vertical e central, flanqueado por elementos laterais simétricos inscritos em quadriláteros.

As tangas de forma 3 e algumas poucas peças de forma 1, no entanto, não apresentam o grande registro "principal" na parte central da peça. Nestes exemplares, o espaço gráfico é tripartido e não quadripartido. Os três registros superior, médio e inferior costumam, então, ser de altura equivalente, e o espaço de separação entre cada um é muito maior que nas demais peças.

O registro inferior corresponde ao estreito ramo inferior da peça, ponta na qual se abre o terceiro furo de suspensão. É marcado geralmente por linhas simples que não chegam a formar figuras.

Veremos mais adiante que cada um desses registros é decorado de forma específica.

Em cinco peças apenas verifica-se a unificação dos campos "médio", "principal" e "inferior” através de uma decoração contínua.

As pintoras marajoara tendo horror ao vazio, os espaços que separam os temas significativos estão ornados por pequenos elementos adventícios que não parecem ter outra que função que a de preencher os interstícios.

Os desenhos são elaborados para se inserirem na forma triangular da tanga, segundo um eixo vertical em relação ao qual as figuras apresentam uma simetria espelhada. Apenas cinco peças fogem a esta regra, por seguirem uma lógica de diagonalização. Enfim, notamos que os elementos de desenho não se completam nos limites do suporte, mas ficam em aberto - da mesma forma que uma paisagem vista de uma janela acaba sendo "recortada" pelos limites da mesma.

A face interna das tangas pintadas não apresenta decoração, mas quase sempre uma faixa periférica de mesma cor que o engobo externo, aplicada por pincel de forma muitas vezes pouco cuidadosa. Na grande maioria das peças, esta faixa tem entre 0,5 e $1,5 \mathrm{~cm}$ de largura, mas pode ser também um pouco mais invasiva. Em cerca de um quarto das peças, no entanto, existe um verdadeiro banho de cor geralmente esbranquiçada, mas eventualmente vermelha ou até cinza ou preta (de carvão?) que recobre toda a face interna. Sobre este banho é frequente ter sido acrescentada a faixa periférica de cor branca ou creme.

No entanto, a maior parte das tangas apresenta hoje, no triângulo central interno, a cor natural da cerâmica - apenas intensificada pelo alisamento ou por um leve polimento. Em 
poucos casos, quando a faixa periférica é mais larga que $1,5 \mathrm{~cm}$ e apresenta limites indecisos e alguns vestígios de tinta aparecem no triângulo central, pode-se perguntar se as peças não teriam sido engobadas internamente. A tinta na parte central teria então desaparecido em razão dos processos de limpeza. A fragilidade das tintas, no entanto, torna improvável que esses artefatos tenham sido normalmente lavados.

As tangas não pintadas - apenas engobadas externamente - apresentam as mesmas características internas; no entanto, não chegamos a registrá-las sistematicamente. (Fig. 3).

\section{Tintas, cores e sua aplicação}

As tangas que apresentam desenhos em sua parte externa foram sempre decoradas por aplicação de tinta, nunca por incisões ou excisões (enquanto estas técnicas são frequentes nas vasilhas marajoaras decoradas).

De fato, e embora se fale tradicionalmente de "tangas policromas", os desenhos são sempre vermelhos, aplicados sobre engobo claro. Trata-se, de fato, de desenhos monocromos.

Os traços dos desenhos aparecem exclusivamente em tons de vermelho, que variam desde uma cor escura, quase marrom, até um ocre claro. Não registramos as cores exatas com
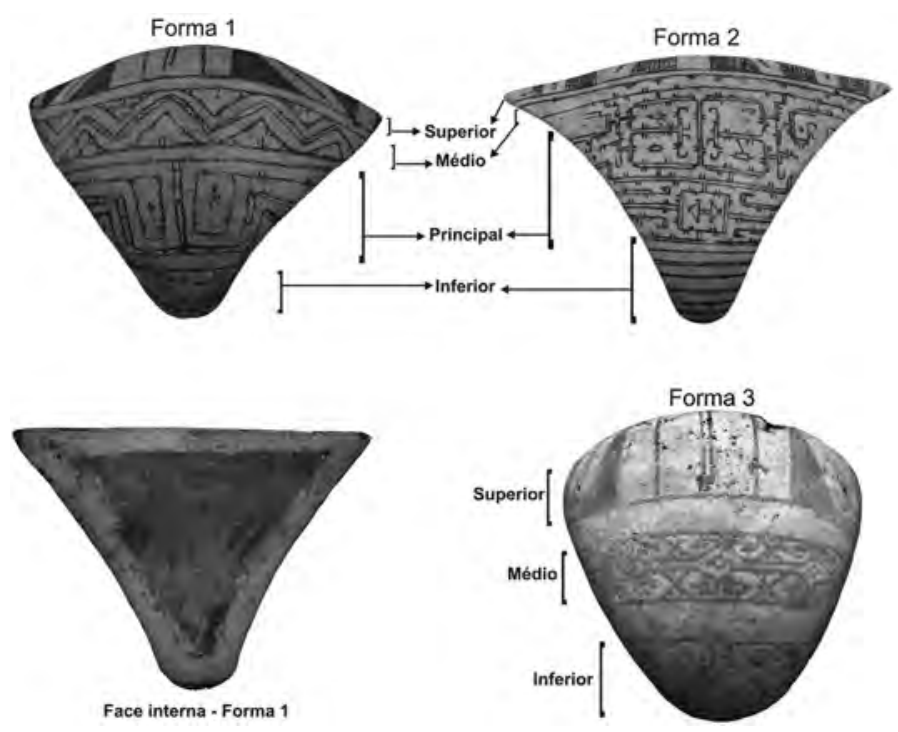

Fig. 3. organização dos campos decorativos. código, pois ficou rapidamente evidente que o colorido se modificava com o tempo e a exposição ao intemperismo. De um setor ao outro do campo decorado, uma mesma linha pode passar progressivamente de um tom escuro (marrom quase preto, como se fosse de manganês) para um vermelho vivo ou vice-versa; ou de um vermelho forte para uma cor desbotada (desde alaranjado para rosado, ou ocre amarelado), chegando a descolorir-se completamente. Esta variação pode depender da diluição da tinta, de fenômenos de oxidação, da exposição à luz e de eventuais contatos acidentais com água ou com o suor. É também possível que certas peças com tons particularmente esmaecidos, hoje amarelado claro ou quase creme tenham sido pintadas com pigmentos vegetais (urucum?), mas nenhuma análise foi realizada até agora para identificar os componentes das tintas. $\mathrm{O}$ engobo das peças com desenhos é sempre de cor clara: branco ou creme; por vezes marfim, rosado, amarelado ou cinzento. As peças apenas engobadas de vermelho, por sua vez, apresentam esta cor em tons geralmente escuros (vermelho vinho). $\mathrm{O}$ aspecto fosco ou levemente brilhante depende provavelmente das condições de preservação. Uma tinta branca (levemente cinzenta ou amarelada) foi por vezes utilizada para preencher o espaço entre os traços paralelos que compõem as linhas duplas de um dos estilos gráficos; em outros casos, parece ter sido utilizada para este mister a mesma tinta dos desenhos, apenas mais diluída - produzindo um tom levemente rosado.

Uns poucos traços brancos discretos, como se fossem guias para um esboço, ocorrem em uma peça que mereceria um estudo especial. Os traços de desenho nunca são muito finos; embora haja algumas peças que apresentem desenhos mais delicados de 0,5 mm de largura, os traços da maioria delas medem entre 0,8 e $1,2 \mathrm{~mm}$; em raros exemplares têm quase $2 \mathrm{~mm}$ de largura. 
A tinta mostra-se geralmente pouco espessa; no entanto, várias tangas com decoração tripartida e de forma 3 apresentam uma tinta excepcionalmente espessa $\left(n^{\circ} 45,116\right)$.

\section{Os elementos gráficos}

Os traçados são lineares, privilegiando as linhas retas; estas são paralelas ou, quando se cortam, fazem-no geralmente em ângulo reto. Formam desenhos lineares (cruzes) ou figuras geométricas fechadas (triângulos, quadriláteros, hexágonos), ou espiraladas (estas não são feitas com uma única linha curva, mas por uma sucessão de segmentos retos ou levemente curvos). As linhas podem ser reforçadas de várias formas: por duplicação (duas linhas paralelas próximas uma da outra, com preenchimento do interstício por uma tinta clara) ou por acréscimo de "aspas" transversais. Quando várias linhas duplas estão adjacentes, articulam-se sempre como se fossem duas réguas em contato apenas com um ponto, não se tocando nunca através da superfície terminal de uma das duas. Linhas oblíquas costumam ser marcadas de um lado por pequenos triângulos que lhes dão um aspecto escalonado. Nos ângulos, pequenos quadrados marcam a junção entre traços perpendiculares, enquanto triângulos diminutos marcam as junções oblíquas - como se faz para caracterizar os ângulos na geometria moderna. As poucas linhas curvas compõem o tronco das figuras zoomorfas ou formam volutas que adornam as extremidades de figuras simples angulosas - particularmente, "ampulhetas", eventualmente reforçadas por pastilhas.

Algumas superfícies são chapadas ou preenchidas por hachuras, mas este recurso costuma ser reservado ao registro superior. Nos demais campos decorativos, as figuras lineares predominam visualmente (a não ser nas cinco peças "diagonalizadas"), sendo muitas vezes exclusiva. (Fig. 4).

\section{$\mathrm{O}$ registro superior}

Já salientamos que as pintoras determinavam a altura do registro gráfico superior em função da categoria morfológica da tanga (maior para a forma 3 , estreita no caso da forma 2 e intermediária para a forma 1). Apenas dois tipos de motivos são utilizados nesta faixa.

O mais comum (ocorre em mais de $80 \%$ das peças) corresponde ao que seria uma evocação da genitália feminina. Trata-se de um retângulo aberto na parte de cima, pintado bem no centro da faixa superior da tanga, que apresenta dois traços verticais paralelos em seu centro. Este mesmo tema se repete lateralmente, só que inclinado de forma simétrica, de cada lado do modulo central, como se formassem pernas abertas. Estes elementos são separados uns dos outros seja por elementos triangulares (87\% das tangas de forma 1) que podem apresentar uma base bem larga ou bem estreita dependendo do tipo de decoração do campo principal, seja por quadriláteros (a quase totalidade das tangas de morfologia 2). Nas peças de forma 1 , tantos os triângulos quanto os quadriláteros estão sempre chapados, enquanto nas peças de forma 2 , costumam ser reticulados (em mais de $85 \%$ das ocorrências), embora alguns sejam chapados.

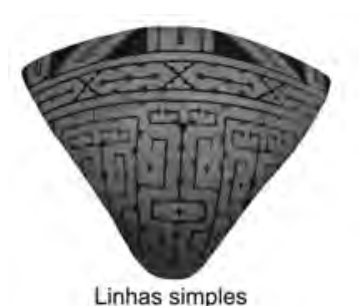

Linhas simples

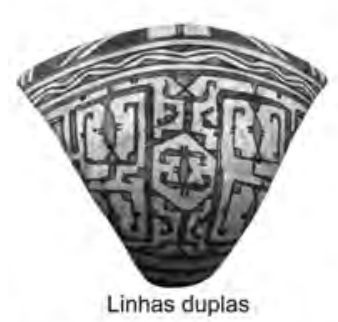

Linhas duplas

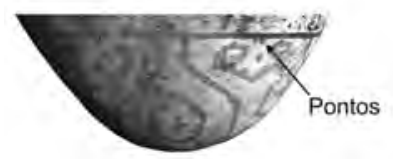

Fig. 4. Elementos gráficos.

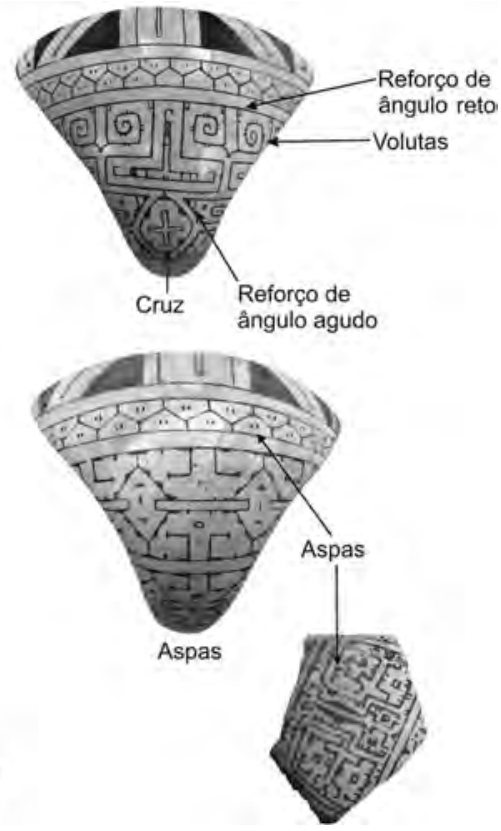


O segundo tema possível, encontrado apenas em algumas peças, corresponde a um alinhamento de pequenos $\mathrm{V}$, geralmente reunidos em uma única linha em zigue-zague. Nas tangas que apresentam esta particularidade, este registro forma uma faixa extremamente estreita ao longo da borda. De fato, o zigue-zague é o tema normal do registro médio. Podemos dizer que, nessas tangas com zigue-zague na borda superior, o registro médio substitui o registro superior; apenas sete peças, dentro dos mais de 140 exemplares observados, apresentam este tema deslocado - entre as quais quatro são miniaturas, provavelmente brinquedos de crianças - ou peças de treino para pintoras inexperientes. (Fig. 5).

\section{$\mathrm{O}$ registro médio}

O registro médio costuma ser o mais estreito de todos nas tangas de forma 1 . Nas peças de forma 3, pelo contrário, torna-se tão larga quanto as demais, e ocupa o espaço central. Nas tangas de forma 2, este campo praticamente desaparece.

Pode-se utilizar, nesta faixa um de dois motivos principais - morfologicamente parecidos: zigue-zague, ou ampulhetas. De fato, esses dois
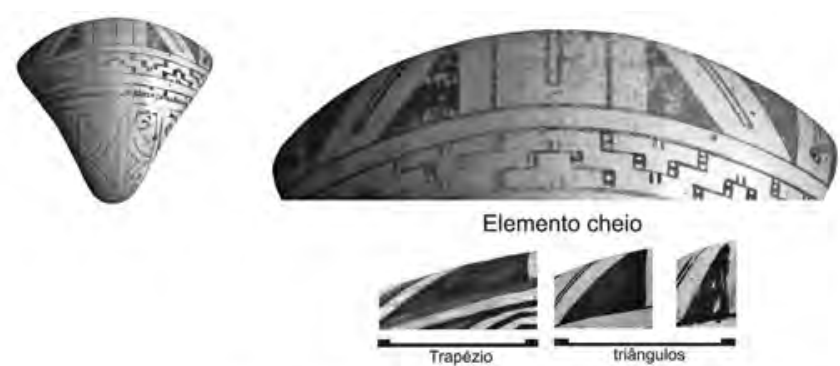

Elemento quadriculado
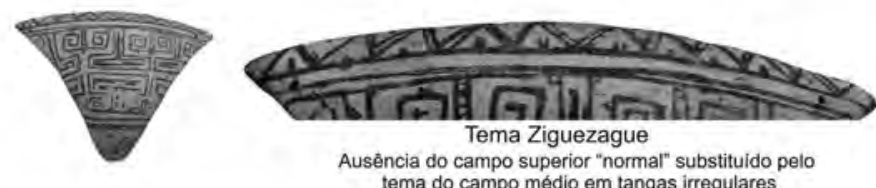

tema do campo médio em tangas irregulares

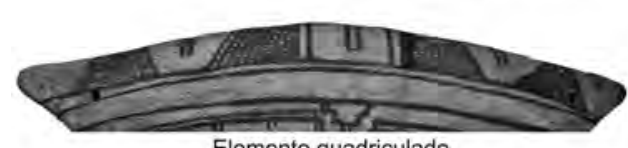

Fig. 5. Tema do campo superior. temas podem ter sido vistos como aparentados, pois uma série de " $\mathrm{X}$ " ou ampulhetas pode ser lida como um duplo zigue-zague. Raros exemplares apresentam outra formula, na qual o motivo nunca deixa de comportar uma estrutura algo parecida com o zigue-zague.

O tema mais frequente (ocupa $34 \%$ dos campos médios observados) é, portanto, o zigue-zague. Pode aparecer na forma de uma linha quebrada - simples ou dupla; pode ser flanqueada por triângulos isósceles que preenchem o espaço superior e inferior; ou trata-se de um espaço vazio ziguezagueante entre dois alinhamentos de triângulos - eventualmente adornado por um elemento em forma de tridente. $\mathrm{O}$ zigue-zague também pode entrar na composição de um motivo que evoca para nós - e para diversos grupos indígenas - um favo de mel ou a escama hexagonal de casco de tartaruga, cujos compartimentos internos (meios alvéolos, ou meias escamas) são marcados por "aspas".

O segundo motivo mais frequente (30\%) corresponde ao desenho em forma de $\mathrm{X}$ ou de ampulheta. Este motivo também apresenta variantes: as ampulhetas podem ser separadas por traços verticais; por um traço horizontal geralmente reforçado por aspas transversais que podem dar-lhe um aspecto biomorfo. Um desenho apresenta até apêndices laterais que reforçam esta impressão. Ou então, duas das extremidades dos X são prolongadas por volutas (esta categoria também pode apresentar uma morfologia discretamente antropomorfa, evocando um corpo deitado); também podem ser realçados os losangos virtuais entre dois módulos em X.

Em 34\% das tangas (inclusive na quase totalidade daquelas de forma 3), este registro é assinalado apenas por duas linhas retas paralelas muito próximas ente si, reforçadas com aspas ou, por vezes, unidas por curtos traços transversais. Este duplo alinhamento tem por função marcar a separação entre o registro 
superior e o registro principal, não se tratando realmente de um registro decorativo. Apenas quatro peças apresentam uma quarta modalidade, na qual o friso é formado por elementos estruturados por linhas oblíquas. Esta fórmula cria um dinamismo visual original que contrasta com as simetrias de translação ou de espelhamento normalmente utilizadas pelos marajoaras. (Fig. 6).

\section{O registro principal}

Encontramos apenas duas categorias de decoração no campo principal. A primeira consiste em uma composição em simetria espelhada cujos elementos compõem um rosto (provavelmente humano), combinado com outros elementos figurativos (Prous 2007). A outra, muito rara, privilegia eixos oblíquos e pode evoluir para uma simetria rotativa.

\section{Os rostos}

A grande maioria (mais de 80\%) das tangas pintadas evoca uma ou várias caras - humana ou animal - cujos elementos são tratados de forma convencional. A boca pode ser (menos de 20\% das peças) sugerida apenas pelas mais altas das linhas horizontais que ocupam o campo inferior. No entanto, costuma ser indicada de forma mais evidente por um desenho poligonal. Por exemplo, por um retângulo com traço horizontal interno; em alguns casos, avistam-se nele triângulos que acreditamos representarem os dentes (uma fórmula que encontramos até agora apenas em peças
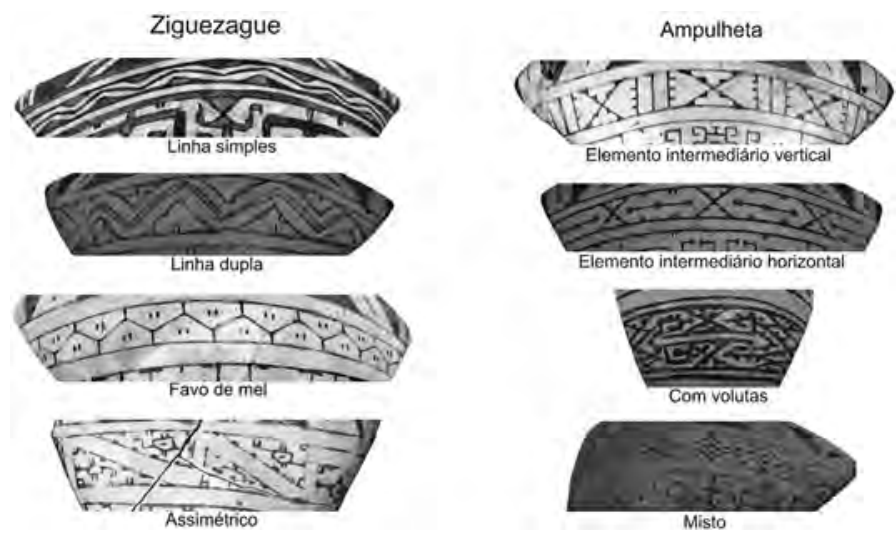

Fig. 6. Tema do campo médio. da coleção T. Wild). Em 13\% das tangas, a boca é figurada por uma espiral ou um losango marcado por uma cruz; ou, ainda, por um triângulo pequeno (10\%); uma figura sauromorfa é também utilizada no lugar da boca (em 10\% dos rostos).

Apenas 6\% dos artefatos cujo campo principal evoca um rosto não possuem nariz figurado. Nas demais tangas, este apêndice é frequentemente $(58 \%)$ representado por uma figura zoomorfa vertical com os quatro membros dobrados. Esta geralmente apresenta um corpo alongado filiforme e espécies de antenas ou mandíbulas; sua forma evoca a silueta de um louva-deus (apesar de ter apenas quatro membros). Outras vezes, o corpo é retangular e o animal se parece com uma barata, também de quatro patas; quando o tronco é biconvexo, a figura lembra um sauro - jacaré ou lagarto. Em várias tangas, o nariz é figurado obviamente por uma cobra de cabeça triangular. Em vez de uma figura zoomorfa, o nariz pode ser representado por um espaço em forma de T invertido $(\perp)$; o ramo horizontal do $\perp$, eventualmente decorado por duas espirais pequenas representando as narinas.

Os olhos são indicados por grandes figuras em espiral ou por espaço quadrangulares (mais raramente, triangulares) preenchidos por pequenos elementos: cruz ou figura vertical biomorfa, cuja morfologia tanto pode sugerir um lagarto quanto um inseto ou o corpo de um peixe. Excepcionalmente, em algumas tangas, os olhos estão figurados por um pequeno retângulo com apêndices biomorfos. Numa tanga muito original, os olhos são figurados por dois rostos que parecem interligados por uma dupla linha hachurada - talvez uma representação de uma serpente bicéfala. Nota-se de passagem que não ocorre representação de escorpião no lugar do olho, ao contrário do que ocorre nas vasilhas marajoaras antropomorfas. Em alguns casos, os olhos, nas tangas, são figuras quadrangulares que, elas mesmas, evocam caras menores (com olhos, nariz e boca). Esses elementos quadrangulares são por vezes repetidos lateralmente, evocando possivelmente as orelhas. 
Tais jogos de utilização de animais para figurar um órgão, representações encaixadas uma na outra (como se fossem bonecas russas) com miniaturização e ressonâncias múltiplas evocam os kennings típicos de várias culturas andinas desde $\mathrm{o}$ período Chavin. Finalmente, notemos que, quando ocorre, o elemento "cabeça de cobra" costuma apresentar-se repetido, em simetria vertical espelhada.

Várias peças apresentam siluetas antropomorfas inseridas no meio da representação de rosto: duas delas apresentam um corpo inteiro em posição semelhante à figura amazônica "tangawa"; um fragmento apresenta um indivíduo filiforme com braços dobrados e dedos; sobretudo, antropomorfos com os quatro membros divergentes formando um $\mathrm{X}$ podem ser visto nas tangas de olho gigante. Um desenho poderia evocar a parte central de um corpo feminino. Uma última peça apresenta quatro silhuetas humanas: uma delas, de tipo "tangawa" é cruzada por outro corpo em forma de Y com forquilha dupla; entre os membros divergentes da primeira figura ainda se veem pequenas figuras antropomorfas com a cabeça colocada diretamente acima das pernas (lembrando algumas gravuras rupestres encontradas nos afluentes de margem esquerda do Baixo Amazonas).

As tangas cujo registro central não evoca um rosto são aquelas que apresentam uma divisão tripartida (incluindo, portanto, as peças de forma 3) ou um campo unificado, fugindo do modelo "normal" de decoração tetrapartido (grupo "tripartido" descrito mais adian- te). Mesmo assim, veremos que a figura humana está presente nestas peças, embora de forma discreta. (Figs. 7, 8a e 8b).
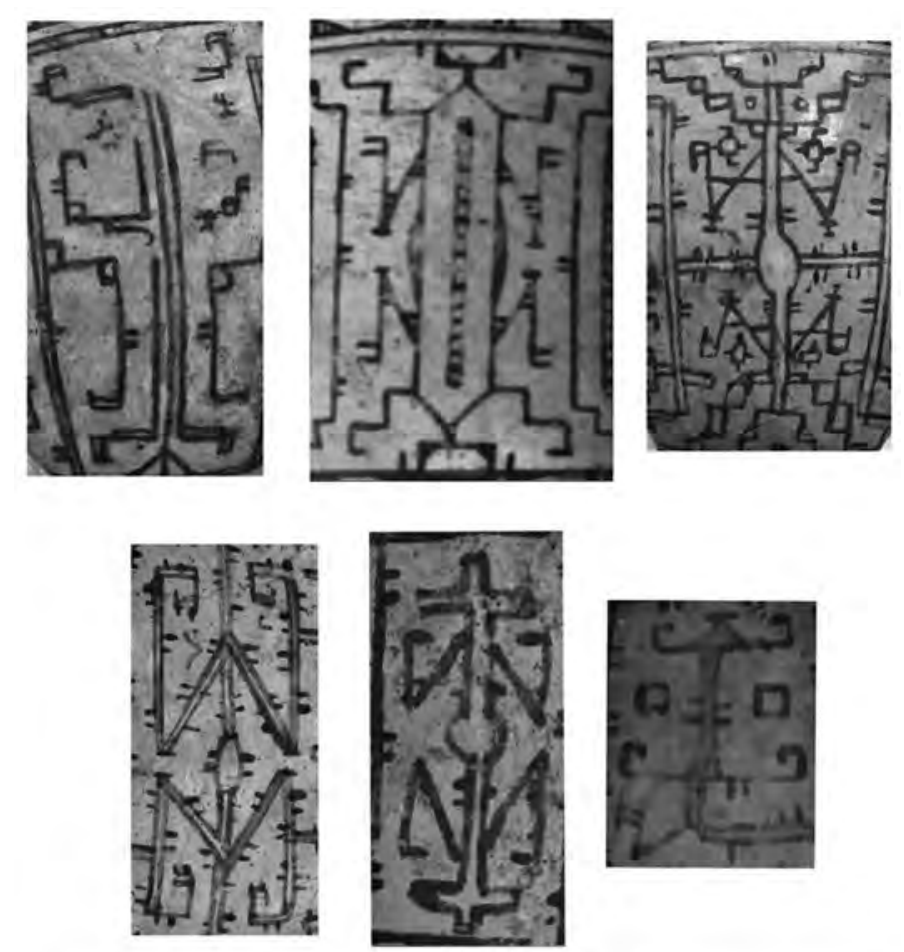

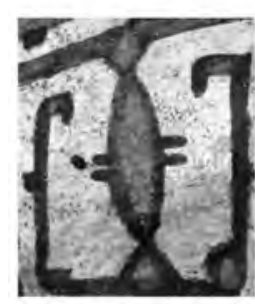

Pisciforme
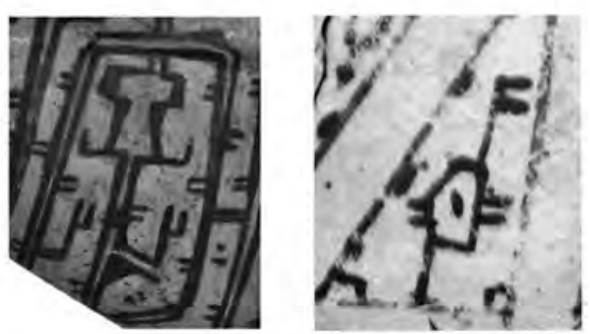

Elementos de preenchimento

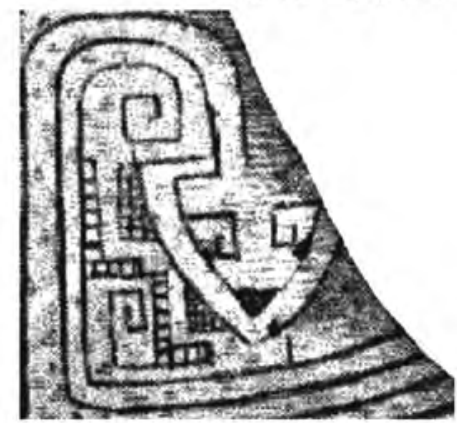

Cobras

Fig. 7. Elementos zoomorfos do registro principal. 


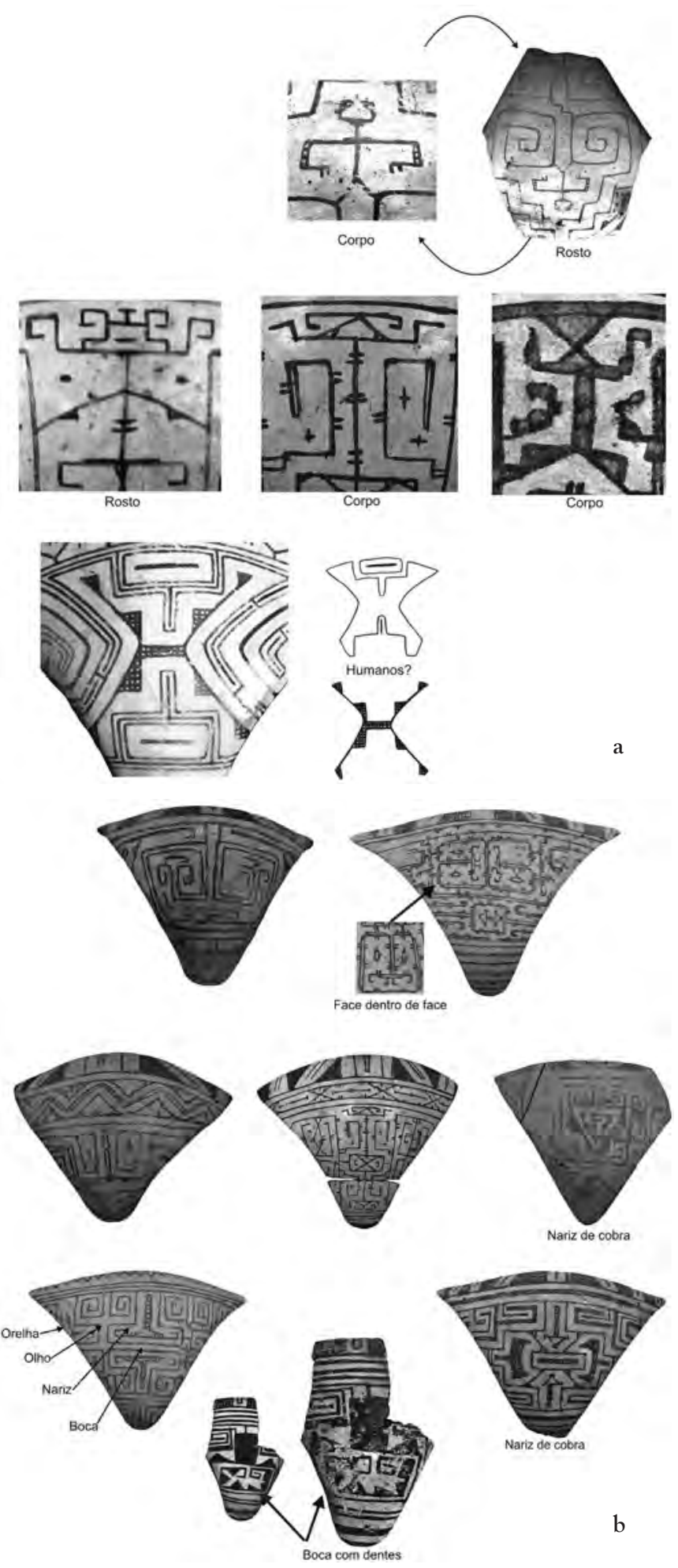

Figs. 8 a e 8 b. Elementos antropomorfos - Faces.
As composições oblíquas

unificando os campos médio e principal

Como mencionamos anteriormente, cinco peças excepcionais apresentam um campo decorativo unificado, no qual nunca aparece a evocação de um rosto. Em três delas, a composições é dominada por eixos diagonais. Duas destas tangas são, à primeira vista, tão parecidas entre si que podem ser creditadas a um mesmo autor, ou à reprodução de um mesmo modelo. Apresentam um motivo escalonado formado por triângulos aplicados em linhas diagonais; este motivo é reproduzido várias vezes por simetria de translação (numa delas) ou rotativa (na outra). Uma terceira tanga tem seu espaço subdividido pelo cruzamento de linhas diagonais com outras, horizontais; cada compartimento assim criado é marcado por um pequeno triângulo interno. As duas últimas peças apresentam um tema talvez derivado do motivo em "favo de mel".

\section{$\mathrm{O}$ registro inferior}

O registro inferior é aquele que costuma apresentar a decoração mais simples. Na maioria dos casos (55\% das peças observadas com os desenhos deste campo ainda legíveis, particularmente entre as tangas de forma 1), trata-se apenas de duas a cinco linhas horizontais simples $(28 \%)$ ou duplas (18\%) ou, ainda alternando-se duplas e simples ( $9 \%$ dos casos), bem espaçadas entre si. Normalmente, uma dessas linhas passa pelo furo inferior da tanga. A horizontalidade das linhas se contrapõe à verticalidade do ramo inferior da peça. 
Outra fórmula ( $17 \%$ das peças observadas) é quase exclusiva das tangas que reunimos no grupo de "divisão tripartida" (ver adiante). Privilegia linhas verticais que seguem o eixo morfológico da parte inferior, combinando-se, no entanto, com curtos traços horizontais perpendiculares. Muito mais raras são representações de cobra (5\% dos registros inferiores) ou de seres antropomorfos ( $9 \%$ dos mesmos), simples ou geminados; nestes casos, os mesmos ofídios ou antropomorfos estão também presentes no campo principal. Poucas tangas apresentam fórmulas originais, não repetitivas.

A extremidade semi-circular do vértice inferior das peças de forma 1 costuma ser pintada de vermelho (em 40\% dos exemplares), o que forma uma mancha colorida em meia-lua cujo peso equilibra visualmente a peça quando vista em exposição. No entanto, deve-se frisar que esta mancha vermelha não devia ser visível quando a peça estava instalada no corpo, com a pessoa em pé ou sentada. Este ponto vermelho terminal não aparece em nenhuma peça de forma 2 e apenas num exemplar de forma 3. (Fig. 9).

\section{A face interna}

A face interna das tangas nunca apresenta desenhos; no entanto, a mesma tinta utilizada externamente como engobo é aplicada (de forma por vezes cuidadosa, outras vezes, com

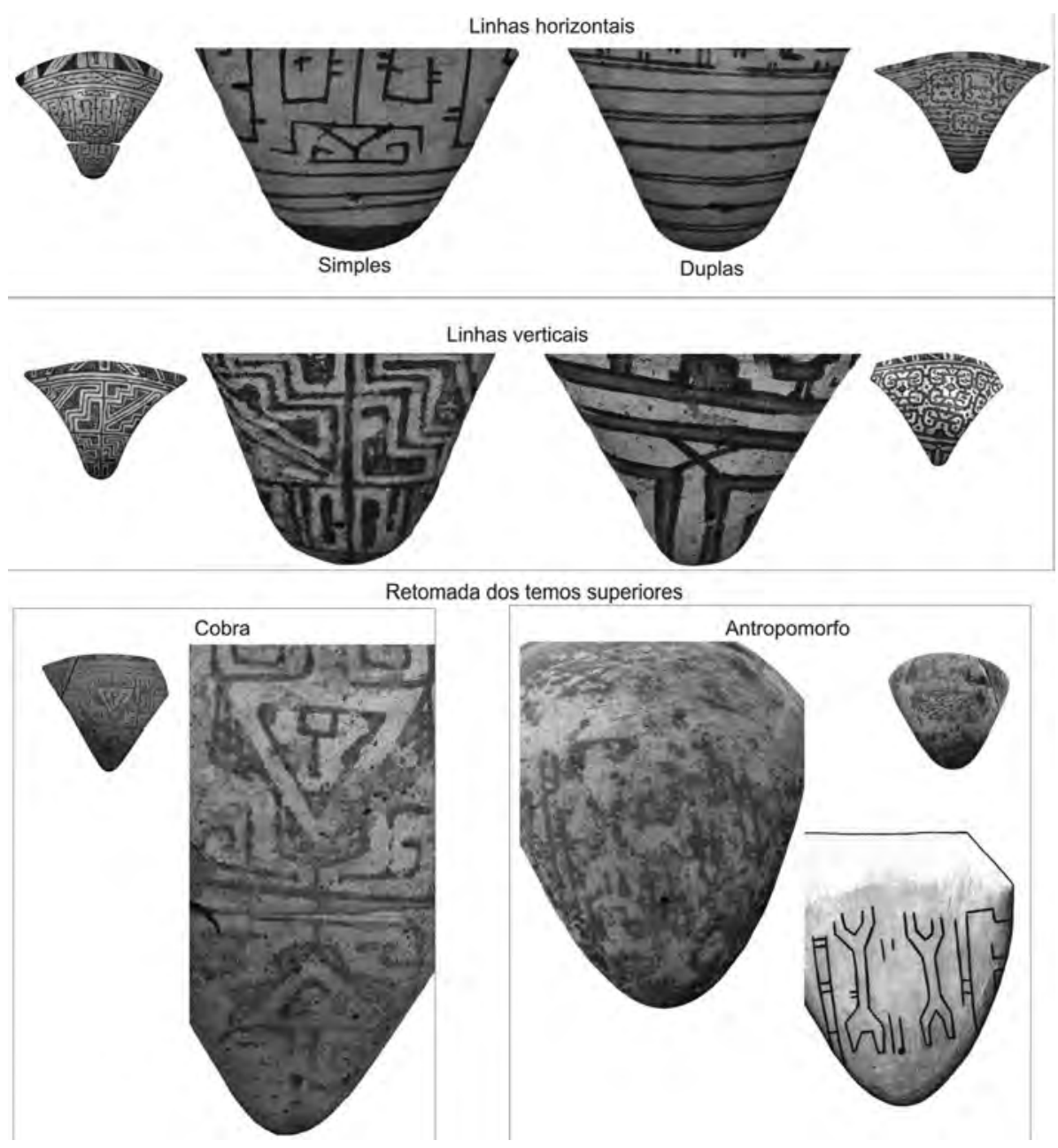

Fig. 9. Registro inferior. 
grandes pinceladas irregulares) no contorno interno das peças, deixando geralmente de cor natural apenas um triângulo central - quase sempre bem polido, ressaltando o contraste entre esta parte alaranjada ou vermelha e a periferia pintada de cor branca ou creme. Algumas peças, no entanto, tiveram o triângulo central da face interna enegrecido.

\section{Utilização e função das tangas}

Quem utilizou e quem fez as tangas e sua decoração?

Não há razão de se questionar a identificação das peças como proteção pubiana; segundo H. Palmatary, algumas teriam até sido encontradas fixadas em urnas antropomorfas no local que representa a parte inferior do tronco - mas trata-se de relatos não controlados.

No entanto, faz falta um estudo especial para avaliar objetivamente quem seriam os usuários, confirmando sugestões já apresentadas, porém nunca reforçadas por argumentos concretos e questões ainda não levantadas até o nosso estudo. Seria a forma 1 adequada para corpos jovens e esbeltos, enquanto a forma 2 , menor, seria mais adequada para pessoas adultas e/ou mais corpulentas? Eram estes artefatos feitos sob medida ou haveria padrões quase estandardizados, como sugerem os gráficos que fizemos a partir das principais medidas? Qual seria a função do abaulamento superior que caracteriza a maioria das tangas de tipo 2? Poderiam ser estas peças utilizadas no cotidiano? Não pretendemos resolver aqui estas importantes questões, embora tenhamos consultado a seu respeito colegas da área de bioantropologia e da moda, de forma preliminar. Antes de se emitir uma opinião bem fundamentada, seria necessário conseguir que várias pessoas de idades e constituição física diferentes experimentassem estas peças arqueológicas, o que parece muito complicado de se realizar. Testes de utilização preliminares, no entanto, foram realizados com réplicas por jovens pesquisadoras de nossa equipe e seu resultado está publicado neste volume (Rodrigues et al. 2011). Outra possibilidade, apesar do desco- nhecimento que temos do padrão morfológico corporal das populações indígenas de Marajó - já que estas desapareceram - seria realizar simulações computadorizadas com auxílio de bio-antropólogos e técnicos de informática.

Por enquanto, parece haver consenso implícito de que estas tangas de cerâmica teriam sido utilizadas por pessoas de sexo feminino; talvez esta opinião seja precipitada, já que ninguém parece ter verificado a possibilidade de algumas delas se adaptarem ao corpo de uma criança de qualquer sexo.

\section{Haveria peças não "funcionais", feitas por ou para crianças?}

Três tangas da coleção MAE/BS - cuja autenticidade não questionamos - assim como outra ( $\left.n^{\circ} 100\right)$, ilustrada por Mordini (1929) e Palmatary (1950) e uma última, do Museu do Arari se destacam pelo seu tamanho diminuto (quatro delas) e sua decoração inusitada (todas elas). Poderiam ser brinquedos para crianças; embora várias tenham perdido suas extremidades laterais, sua largura original pode ser estimada entre 8 e $10 \mathrm{~cm}$, enquanto sua altura varia entre 8 e $9 \mathrm{~cm}$. A sua morfologia é "normal" (uma delas apresenta a forma 1, os outras, a forma 2). Os três exemplares do MAE/BS apresentam um campo superior incomum: traços verticais ou barras inclinadas aludindo ao tema em ziguezague, porém com os elementos em descontinuidade; não apresentam campo médio. A tanguinha da coleção Oliveira, ilustrada por Mordini e Palmatary, por sua vez, não apresenta nenhum dos dois campos mais altos. Nestas quatro peças, o campo principal propõe elementos "clássicos", porém tratados de forma "diferente". Numa delas se reconhece a representação de uma "cara", mas os olhos são tratados na forma de X barrados em seu centro por um colchete. Trata-se obviamente de uma alusão ao tema ampulheta do campo médio costumeiro, desvirtuado da sua situação (normalmente na segunda faixa), da sua função (normalmente, cada X deveria ser um elemento de friso) e com execução irregular (o colchete mediano). O nariz em T é também executado de forma anormal, com exageração do que 
poderiam ser interpretadas como narinas. A miniatura da coleção Oliveira recebeu apenas uma figura, em forma de ampulheta. Na quarta tanguinha, uma figura biomorfa ocupa o centro de simetria de uma das tangas, como no tema do "nariz-lagarto"; no entanto, o traçado é largo e curvilíneo. Em todas as três miniaturas do MAE/BS pode se verificar a segurança do traço: os pintores sabem usar seu pincel; no entanto, a execução dos traços ou a realização dos elementos manifestam um desvio em relação aos padrões gráficos. Assim sendo, não pensamos atribuir estes "deslizes" à incapacidade de crianças que estariam aprendendo a decorar as tangas; acreditamos que elas tenham sido pintadas por pessoas já desenvolvidas e com bom controle motor. As duas peças nas quais se verificam o desvirtuamento dos elementos gráficos, porém com utilização das normas gráficas de desenho poderiam, talvez, ser creditadas a mulheres. Estas preparariam para suas criancinhas tangas decoradas, mas privadas de elementos significativos proibidos para pessoas não iniciadas. Sugerimos que a peça decorada de forma curvilínea, por sua vez, talvez tenha sido pintada por um homem. Com efeito, há uma tradição bastante geral de os homens e mulheres das terras baixas sul-americanas desenharem de forma diferenciada. As mulheres expressando-se através de estilos geometrizantes e através de figuras ortogonais, enquanto os homens tendem a fazer desenhos mais livres e curvilineares ( $\mathrm{Ri}$ beiro 1961). A decoração da tanga do Museu de Cachoeira do Arari, por sua vez, apresenta uma tosca evocação de rosto, mas riscada com traços grossos e inseguros, cujo desenho revela uma pessoa ainda pouco habilidosa. Maior que as anteriores (embora com curvatura muito fraca) e com furos apresentando marcas de desgaste, esta peça poderia ter sido utilizada por uma pessoa mais crescida. Uma última tanga irregular, de dimensões normais, porém de arqueamento muito fraco $(3,7 \mathrm{~cm})$, carece do registro típico do campo superior. Abaixo do zigezague, mostra uma decoração do campo principal aberrante, embora enquadrada por dois grandes "olhos" quadrangulares semelhantes àqueles das tangas do grupo "Camutin". (Fig. 10).
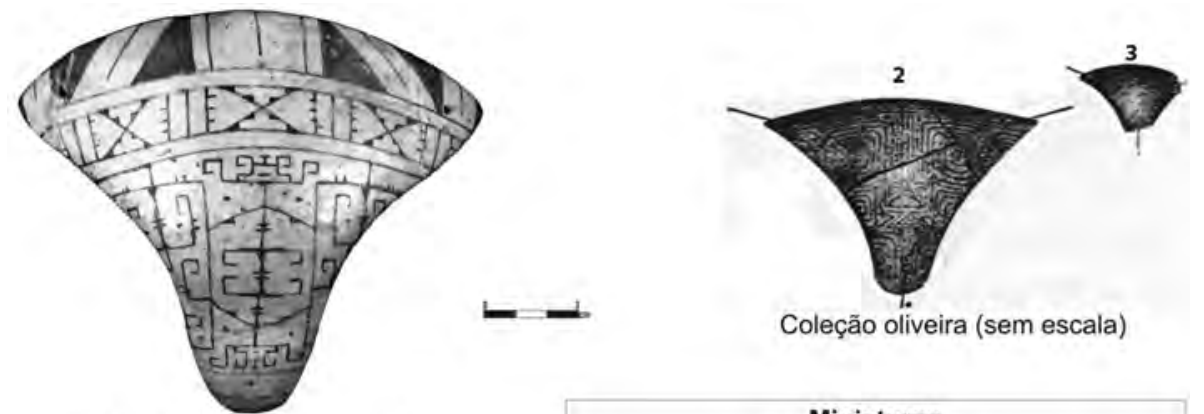

Peça de tamanho normal
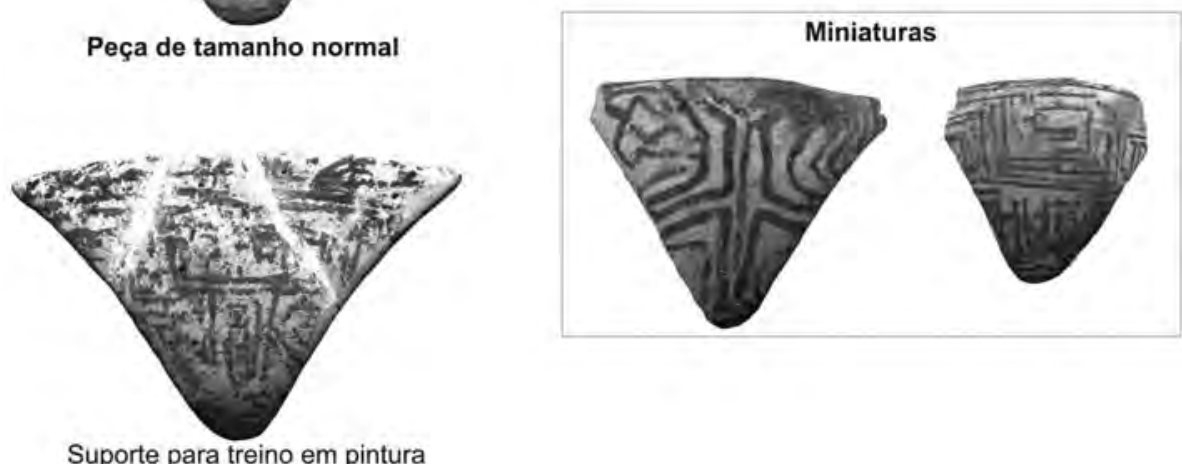

Fig. 10. Miniaturas e suporte para treino. 
O quanto as tangas foram utilizadas?

\section{Fragilidade das tintas}

Inicialmente, salientaremos o fato de que as tintas dos desenhos parecem frágeis: traços de alguns desenhos apresentam indícios de diluição dos pigmentos por terem sido as tangas expostas a respingos de água (antigos ou recentes). Uma pessoa nos confirmou ter lavado uma peça com muito cuidado, sem ter conseguido impedir o desaparecimento dos traços. Esta instabilidade implicaria a impossibilidade de utilização no exterior das casas, pelo menos durante a estação chuvosa (de longa duração nesta região equatorial) ou durante atividades que impliquem contato com água ou um escorrimento abundante de suor na face externa da peça. $\mathrm{O}$ problema seria menor no caso das tangas apenas engobadas, que poderiam receber facilmente um novo banho vermelho. De qualquer forma, Mordini observa que os desenhos de uma das peças da sua coleção de fragmentos apresentam sinais de terem sido repintados. Tivemos a mesma impressão ao examinar uma das tangas do Museu Goeldi; no entanto, pareceu-nos que os traços em branco vislumbrado na parte central desta peça, erodida, poderiam apenas resultar da queda dos pigmentos vermelhos; estes teriam levado consigo a parte superficial e patinada ou suja do engobo, deixando aparecer a cor mais clara do caulim (?) original. Se isto for, não haveria pintura nova sobre traços anteriores (não se entende, inclusive, porque teriam pintado desenhos em branco sobre um fundo claro), mas percepção do negativo dos traços pintados, hoje desaparecidos. Caso esta observação nossa valha para a peça comentada por Mordini, não haveria motivo para acreditar que as tangas decoradas seriam pintadas com desenhos várias vezes - nem haveria, portanto, comprovação de utilizações repetidas.

\section{Desgaste dos furos de suspensão}

À primeira vista, parece óbvio que o grau de desgaste dos furos de suspensão poderia fornecer indicações sobre a frequência de utilização das tangas - uso quotidiano, ou restrito a circunstâncias ocasionais e, provavelmente, cerimoniais.
Vimos que B. Meggers e C. Evans já tinham observado nesta perspectiva os furos de várias peças - porém sem diferenciar as formas de desgaste, nem os orifícios laterais e inferiores entre si, nem comparando as marcas existentes nas faces interna e externa. Decidimos prestar atenção, portanto, aos orifícios de suspensão das tangas - seja apenas engobadas, seja com superfície desenhada - que pudemos observar pessoalmente (mais de 140 peças). De qualquer forma, é preciso salientar que, para se interpretar de forma mais segura as marcas "de utilização", seria necessário conhecer a força abrasiva dos cordões (quantidade de fitólitos nas fibras) e a dureza das tangas, além de se esperar o resultado do trabalho de experimentação com réplicas usadas por pessoas vivas. Não apresentaremos aqui nenhuma quantificação dos dados que registramos, em razão do caráter incompleto e preliminar das nossas observações. Com efeito, não registramos de forma objetiva o grau de profundidade do desgaste; faltam uma ou duas extremidades de muitas peças - e, portanto, as perfurações correspondentes; outras estão tampadas ou preenchidas por sedimentos; enfim, duvidamos da autenticidade de várias tangas apenas engobadas. Mesmo assim, estamos em condições de apresentar algumas considerações de ordem geral.

Os furos são muito pequenos (orifícios entre 1,5 e 2,3 mm de diâmetro; geralmente entre 1,8 e 2,0 mm) - excluindo-se algumas peças de autenticidade duvidosa. $\mathrm{O}$ fato de quase todos eles estarem preenchidos por terra impediu verificar se haveria estreitamento interno (seção bicônica ou cilíndrica). De qualquer forma, os cordões de suspensão tinham que ser muito finos (com diâmetro máximo de cerca de $2 \mathrm{~mm}$ ). Os furos superiores (dos ramos laterais) apresentam um desgaste mais marcado na face externa, que se manifesta pelo desenvolvimento lateral e pouco oblíquo de uma goteira ou canaleta. Esta pode existir apenas na espessura do engobo ou aprofundar-se na pasta da cerâmica. Pode ser apenas esboçada - sobretudo na face interna. Bem mais raramente, nota-se um desgaste periférico ao redor do orifício externo ou interno.

O furo inferior, por sua vez, apresenta um padrão de desgaste desenvolvido essencialmente na face interna, onde estes furos inferiores 
apresentam um micro desgaste periférico (contornando todo o furo, ou apenas presente em metade ou dois terços da sua periferia), eventualmente prolongado para baixo por um esboço de goteira. Na face externa, o desgaste é mais raro que nos furos superiores e se manifesta também, sobretudo, na forma de micro descamações; algumas peças, no entanto, apresentam uma canaleta externa dirigida para baixo, em geral apenas incipiente.

\section{Forma de amarração}

Destas observações, e como não existe desgaste linear atravessando a largura das peças, podemos deduzir que as duas extremidades de um mesmo cordão seriam amarradas aos furos superiores; ou então, dois cordões diferentes presos cada um a uma das extremidades superiores estariam amarrados atrás do corpo. Pode-se supor que estes cordões seriam fixados por um nó interno e sairiam pela face externa; seriam puxados para o exterior de forma pouco oblíqua em relação à horizontal. A localização e o desenvolvimento maior das canaletas sugerem que os cordões superiores seriam submetidos a uma pressão relativamente forte. $\mathrm{O}$ cordão inferior, por sua vez, também seria segurado por um nó interno; seria, salvo exceções, menos esticado - formando-se mais desgaste interno e periférico em razão da movimentação transversal do corpo. Chegamos a pensar que os furos de algumas tangas, que apresentam canaletas muito longas e profundas, poderiam ter sido feitos voluntariamente pelas fabricantes (para manter os cordões) ou por colecionadores (para passar arames e suspender as peças em mostruários de parede - como parece ter ocorrido na coleção Oliveira fotografada por Mordini), mas isto parece improvável para a maioria das peças.

Como muitas tangas não apresentam desgaste visível a olho nu poder-se-ia também supor que teriam sido pouco usadas. Na coleção do Museu Paraense Emílio Goeldi, por exemplo, a porcentagem de peças com furos apresentando marcas de desgaste é maior entre as tangas policromas do que entre as monocrômicas observadas - ao contrário do que ocorreu nas peças observadas por Meggers \& Evans. Tanto as peças policromas quanto aquelas simplesmente engobadas apresentam a mesma variação de desgastes; por este critério, teriam sido utilizadas com a mesma intensidade. Diante destas informações contraditórias e na falta de estudos experimentais, é prudente não arriscar conclusões sobre a frequência de utilização das tangas. Seria, sem dúvida, importante realizar um estudo especifico dos sistemas de suspensão, após limpeza cuidadosa dos orifícios.

O desgaste em forma de canaleta parece-nos contraditório com uma utilização da tanga por uma pessoa em movimento: o balancear das cadeiras deveria friccionar o cordão num arco de círculo cujo epicentro seria o furo, abrindo uma zona de desgaste angular, em forma de leque, com desgaste maior na bissetriz. Ora, com duas exceções (inclusive uma peça possivelmente falsificada) os maiores desgastes superiores externos são direcionados linearmente, sendo a canaleta rigorosamente reta, estreita, e de bordas paralelas. Tal canaleta somente poderia ser causada por uma fricção linear reta, unidirecional, semelhante àquela produzida por uma serra; ora, isto não corresponde ao movimento complexo decorrente de um corpo humano em movimento.

Outras observações, "de senso comum", podem ser equivocadas, tais como aquela que atribuiria uma frequência maior de utilização a peças com marcas de desgaste maior nos orifícios. Por exemplo, a ausência de desgaste na parte externa dos furos superiores pode resultar não da falta de uso, mas da utilização da peça por uma pessoa corpulenta (comunicação verbal de A. de Tugny). O cordão, neste caso, ficaria pressionado para fora, e não para dentro da tanga, não havendo razão para que imprima sua marca na cerâmica. Ou seja, apenas uma experimentação intensiva permitiria se chegar a uma conclusão sobre as condições de utilização destas peças. Remetemos o leitor ao artigo publicado neste volume (Rodrigues et al.), que apresenta as primeiras experiências que realizamos no Museu de História Natural da UFMG.

\section{Outros indícios possíveis de utilização}

O desgaste dos furos não é a única forma de alteração registrada na cerâmica. Nota-se 
em várias tangas (sejam elas com desenhos ou apenas cobertas por um banho de cor) uma erosão particularmente marcada na parte inferior da face interna - embora remonte por vezes lateralmente, e na parte inferior externa das tangas. Manifesta-se por uma série de pequenas descamações em forma de micro cupules que tornam a superfície rugosa, lembrando o aspecto das paredes de igaçabas supostamente utilizadas para preparar bebidas fermentadas (Skibo 1992). Inicialmente prestamos pouca atenção a este fenômeno, que nos parecia decorrer de uma erosão natural ou, em alguns casos, de bruscas variações de temperatura pós-deposicionais (cupules térmicas). A situação recorrente dos locais afetados, no entanto, levou-nos a considerar a possibilidade de tratar-se de uma alteração relacionada ao contato com o suor corporal, que deve ter sido particularmente intenso nesta faixa periférica. A acidez das secreções também poderia ter contribuído a estas transformações. O cuidado em se pintar internamente a periferia (em contato mais estreito com o corpo) e a ponta inferior (mais submetida ao calor corporal) pode ser interpretado como uma forma de diminuir a erosão das superfícies. Este tipo de alteração ocorre tanto em peças e fragmentos vermelhos quando pintados. (Fig. 11).
Para que estas tangas de cerâmica?

É difícil avaliar a intensidade de produção de tangas ao longo dos muitos séculos de existência da cultura Marajoara, pois quase todas são provenientes de escavações antigas ou ilegais. Podemos notar que as peças apenas cobertas de vermelho são menos numerosas que as com desenhos nas coleções, mas são provavelmente sub-representadas em razão do seu menor valor estético. Poderia se comparar o número de vasilhas decoradas marajoara e de tangas conhecidas, mas um tal trabalho ultrapassaria os limites desta pesquisa. Segundo D. Schaan (2007), nas maiores urnas - que são também as mais decoradas - encontrar-se-iam apenas tangas vermelhas. A partir desta observação, sugere que as peças monocromas seriam destinadas às mulheres maduras, enquanto as desenhadas teriam sido feitas para as meninas em fase iniciática. Esta interpretação baseia-se provavelmente na ideia corrente de que todas as tangas vermelhas seriam de tipo 2, enquanto as de tipo 1 seriam policromas - o que mostramos ser absolutamente inexato. De fato, as seis tangas encontradas em urnas de Camutins, listadas por D. Schaan são todas de forma 1. A. Mattos (1938: 150) cita o texto no qual Derby diz ter achado duas tan-

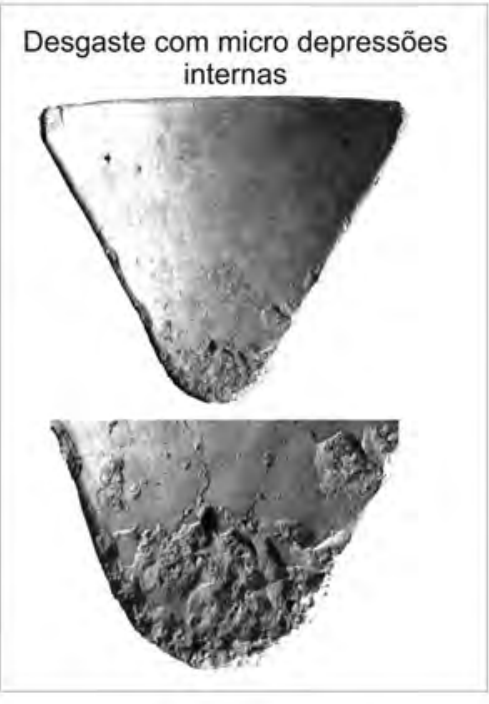

Fig. 11. Desgastes de utilização.

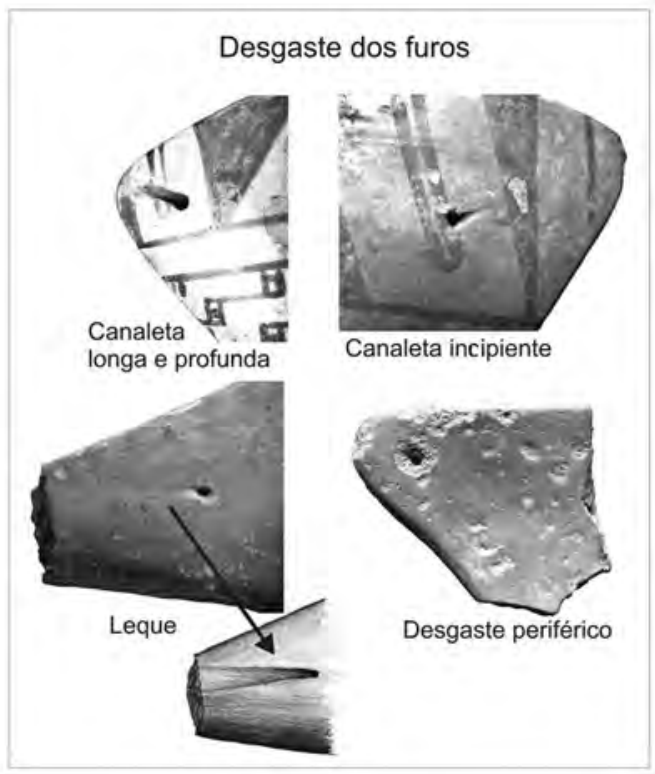


gas em Pacoval "Em dous casos achei dentro das igaçabas as chamadas tangas... a igaçaba tinha sido enterrada dentro de outra maior, e a tanga achava-se no espaço entre as duas... a igaçaba representava uma mulher". Infelizmente, o trecho citado não esclarece a forma das tangas, nem se elas eram decoradas ou apenas engobadas. De fato, com tão poucas referências, não se pode afirmar uma relação exclusiva entre enterramentos e tangas monocromas. Muito menos se pode pensar que as últimas seriam fabricadas para o ritual funerário, já que várias apresentam marcas de utilização.

Afinal, qual poderia ser a razão de se usar tangas de cerâmica, provavelmente muito mais incômodas que as proteções vegetais normalmente utilizadas pelas indígenas? A resposta mais provável é que se trataria de peças de alto valor simbólico utilizadas em rituais e/ou para expor o status de quem as trazia. Citando Steward e Métraux, B. Meggers e C. Evans (1957) referem-se à existência de tangas de cerâmica entre índios de língua Pano do Ucayali (alta Amazônia peruana) - no final do século XIX: “Tossmann (1928 \& 1930) reports that a group of pubescent Chama girls were assembled at full moon, while men and women danced all night and drank from special zoomorph pots. Next morning, the girls were painted, stupefied with drink, then each laid on a bench where an older woman cut off and burial the clitoris and labia. Reich (1903) adds that the girl was deflowered with a clay penis representing his fiancé. The girl was then isolated in her hutt for one month, wearing an egg shaped piece of pottery as a pubic cover." (Steward \& Métraux 1948: 585). Implicitamente, Meggers e Evans sugerem uma utilização algo parecida para pelo menos parte das tangas marajoaras. Uma apresentação de D. Schaan (com. pessoal) mostra uma tanga associada a uma vasilha zoomorfa, a um banco e a um pênis de cerâmica, todos procedentes de tesos de Marajó. A coincidência merece ser apontada, mas é obviamente difícil, no estágio atual dos conhecimentos, demonstrar a existência de uma origem comum para ocorrências observadas nas duas regiões mais afastadas da bacia amazônica e separadas no tempo por mais de meio-milênio - uma distância temporal que era desconhecida em 1957.

\section{Elementos estilísticos}

Tentamos verificar a existência de elementos que permitiriam agrupar as tangas em categorias tipológicas combinando suas características morfológicas e decorativas. A partir da observação de uma dezena de peças, Mordini já tinha contrastado as pinturas de Pacoval com as do Teso do Severino. As primeiras seriam caracterizadas pela presença de módulos claros sobre fundo escuro na parte superior (tema hoje interpretado como genitália) e por uma elaboração gráfica mais tosca; as do teso do Severino não apresentariam o motivo referido. Por outro lado, os desenhos deste sítio seriam mais elaborados que aqueles de Pacoval. Infelizmente a ausência de origem precisa para quase $90 \%$ das tangas que pudemos observar não nos permite aplicar a mesma linha de raciocínio para os diversos sítios da ilha.

Assim, apresentaremos a seguir algumas observações sobre a recorrência de associação entre pares de elementos morfológicos, temáticos e gráficos, sem saber se eles traduzem mudanças temporais, oposições sociais, ou idiossincrasias de fabricantes.

O primeiro ponto que destacaremos é que a oposição mencionada por todos os autores entre tangas com cava profunda (nossa forma 2) e engobo simples, e tangas pouco cavadas (nossa forma 1) e decoração policroma não pode ser sustentada em nível geral. Com efeito, $36 \%$ das peças pintadas apresentam morfologia de tipo 2 (extremidades laterais pontudas e compridas, e cavas geralmente profundas), enquanto a maioria $(57 \%)$ das peças que receberam somente um banho vermelho são de forma 1 .

Isto não significa que as observações feitas anteriormente tenham sido erradas. Apenas acreditamos que esta divisão entre cavadas / engobadas e não cavadas / pintadas possa ter ocorrido em determinados sítios (por exemplo, Pacoval e Camutins) e/ou épocas, enquanto outras comunidades locais não diferenciariam a decoração em função do suporte. Isto explicaria que a maioria das peças conservadas no Museu Goeldi obedeça à oposição proposta tradicionalmente, enquanto isto não ocorre nas outras coleções, cujas peças provavelmente venham, pelo menos em parte, de outros tesos. 
A presença de tangas apenas engobadas com branco (e não com tinta vermelha) nos rios Câmara e Goiapí (Simões 1967; algumas peças também recobertas por um banho de cor creme ocorrem na coleção T. Wild) sugere também a possibilidade de haver códigos locais diferentes. No entanto, a raridade destas tangas brancas autoriza outra hipótese: poderiam ser suportes destinados à pintura, porém abandonados antes de se realizar a decoração.

Outros elementos, estes relacionados aos temas pintados ou a forma de representação, podem ser correlacionados com maior segurança à morfologia dos suportes. Já vimos, por exemplo, que os módulos triangulares e quadrangulares do motivo "genitália" no registro superior são completamente pintados (por aplicação de tinta chapada) nas tangas de forma 1 , enquanto são quadriculados nas tangas de morfologia 2 .

Notamos também que o registro médio (temas do zigue-zague e da ampulheta) ocorre sistematicamente em posição alta na forma 1 (estando então bastante estreito), enquanto ele se torna muito largo e ocupa a posição central na forma 3. Na forma 2, quase desaparece, sendo reduzido a uma simples linha dupla. Por outro lado, a variante "casco de tartaruga" ou "favo de mel" no zigue-zague do registro médio é geralmente associada ao rosto que apresenta o nariz em forma de $\perp$ (de base larga). A este mesmo nariz costuma estar associada uma boca de forma losângica. A maioria das bocas quadradas marcadas por uma cruz interna, por sua vez, é dominada por um nariz cujas narinas são terminadas por um grafismo em forma de tri-dígito (extremidade de pata?).

Parece prematuro definir estilos, enquanto não podemos confirmar sua operacionalidade a partir da cronologia ou de uma repartição geográfica específica. De fato, haveria várias formas de se agrupar as peças tipologicamente a partir da decoração. Por exemplo, poder-se-ia privilegiar determinados temas, opondo as peças que os possuem e aquelas que não o apresentam. Desta forma se contrastariam as composições com e sem "nariz biomorfo"; as tangas com ampulhetas versus peças com zigue-zague no segundo registro; os exemplares que ostentam explicitamente a figura da cobra no campo principal e os que preferem o tema do quadrúpede. Ainda se podem procurar oposições a partir de traços técnicos de desenho - os desenhos elaborados com traços duplos ou feitos com linha simples etc. As seguir tentamos elaborar uma classificação cujas categorias não fossem determinadas por uma única variante, mas pela convergência de várias características associadas entre si. Desta forma, determinamos "grupos" - categorias provisórias de peças que nos parecem, de forma ainda bastante intuitiva, apresentar semelhanças significativas entre si.

\section{Os grupos de peças parecidas entre si}

\section{Grupo "Camutins"}

Esta categoria estilística de decoração bem definida corresponde a 16 tangas e alguns fragmentos, cujos desenhos são feitos com traços duplos. Todas elas apresentam um tema central zoomorfo filiforme alongado (quase sempre sauromorfo) de membros geralmente dobrados; esta figura atravessa verticalmente o campo principal, representando o "nariz" do rosto. A parte central do corpo pode ser alargada em círculo ou quadrilátero de tamanho reduzido. Figuras vagamente pisciformes menores, de corpo geralmente biconvexo, estão dispostas horizontalmente nos quadriláteros laterais ("olhos" do rosto). Em várias peças assim decoradas, a organização dos elementos, embora mantendo a simetria espelhada predominante nas tangas, não deixa de apresentar também uma simetria de translação no sentido vertical, com várias linhas de "lagartos deitados". Não existe relação obrigatória entre a utilização dos traços duplos e a forma do suporte, embora a grande maioria das tangas assim pintadas tenha suporte de forma 2, com o tema do registro superior quadriculado e sem friso de campo médio (nem ziguezague, nem ampulhetas); algumas outras, no entanto, foram pintadas em suporte de forma 1 , apresentam as figuras superiores chapadas e o registro médio decorado por ziguezague.

A esta categoria pertencem peças provenientes das escavações de B. Meggers e C. Evans no teso 1 de Camutins - por isto a denominação do grupo. 
Há outras duas peças muito parecidas, com linhas duplas e o mesmo tratamento "barroco", mas não apresentam o "nariz" zoomorfo; consideramo-nas, no entanto, aparentadas a este grupo.

\section{Grupo dos corpos "imbricados"}

Esta categoria comporta vinte peças e vários fragmentos, todas de forma 1 , com organização geral muito parecida com a do grupo "Camutins”. O aspecto visual é, no entanto, bem diferente - em parte pela utilização de linhas simples e não dupla, e também, pela simplicidade maior dos elementos de reforço, que contrasta com o aspecto barroco das tangas do grupo "Camutins". Distinguimos duas variantes.

O motivo do registro superior é sempre chapado. Na variante principal, o registro intermediário é sempre ocupado por ampulhetas - estas, separadas por traços (seja verticais seja, mais frequentemente, horizontais) eventualmente pisciformes. Em todas as pecas, o registro principal apresenta a face canônica, com um rosto central. Os olhos costumam ser indicados por elementos muito pequenos e discretos: ponto, micro quadrilátero ou micro-círculo, no meio de uma "órbita" formada por uma linha quebrada terminada em gancho. $\mathrm{O}$ nariz deste rosto apre- senta o mesmo tema vertical e axial zoomorfo que as peças do grupo Camutins, porém mais filiforme ainda, marcado em seu centro por um quadrilátero ou hexágono. Os membros não são dobrados junto do corpo, mas se apresentam estendidos lateralmente, com apenas suas extremidades dobradas. Ao mesmo tempo, os interstícios entre os traços delimitam no centro da peça duas superfícies simetricamente opostas que evocam uma silhueta antropomorfa, de membros dobrados abertos. Esta mesma silhueta aparece em outros grupos, de forma mais evidente, seja em posição central, seja como motivo inferior. Lateralmente, os dois quadriláteros que sugerem orelhas apresentam internamente uma versão reduzida do rosto central. Em algumas peças, elementos de reforço nas linhas em forma de gancho as fazem parecer com patas de insetos.

Outra variante agrupa apenas três peças, cujo registro médio é formado por um zigue-zague, enquanto a figura zoomorfa central é tratada de forma original.

Quatro peças apresentam elementos tanto do grupo "Camutins" (parte dos traços duplicados; morfologia do animal que representa o nariz), quanto do grupo de "Corpos imbricados”. De fato, podemos considerar que os dois grupos anteriores são muito próximos e formam um “supergrupo" (“A”). (Fig. 12).

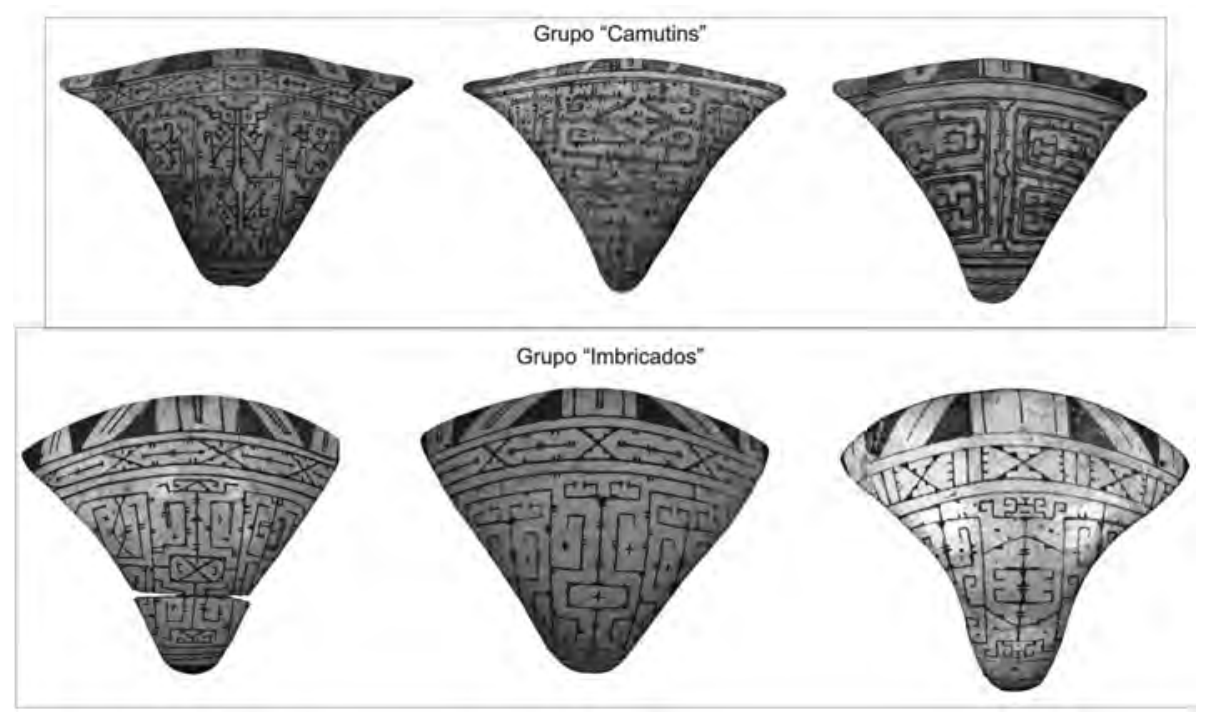

Fig. 12. Tipologia: Supergrupo "A". 


\section{Grupo do "nariz alargado"}

É formado por dezenove peças - quase todas de forma 1 - e quatro fragmentos, que podem ser agrupados em dois subconjuntos. No registro principal podem-se ver uma ou três representações principais de rostos, caracterizados por um elemento em forma de $\mathrm{T}$ invertido $(\perp)$ bem delimitado, abaixo do qual se destaca um losango ou um pequeno hexágono - fechado ou espiralado.

Existem duas variantes. Na primeira (variante "a"), o registro superior apresenta seus elementos chapados. O zigue-zague do registro médio é quase sempre realizado na forma do motivo "favo de mel / casco de tartaruga", que aparece quase exclusivamente nas tangas pintadas deste subgrupo. Os três rostos principais, alinhados na parte mais alta do registro principal. $\mathrm{O}$ elemento em $\perp$ poderia estar representando apenas o nariz; neste caso, a boca - aberta - poderia ser sugerida pela espiral ou pelo losango imediatamente inferior. Outra leitura é, no entanto, possível: o ramo vertical do $\perp$ figurando o nariz, enquanto o ramo horizontal evocaria uma boca fechada (ou semiaberta: duas peças apresentam este ramo horizontal barrado por pequenos traços que poderiam representar dentes). Neste caso, a espiral inferior não representaria nenhum elemento da face. Os olhos são evocados por elementos espiralados; os olhos de 2 rostos vizinhos são reunidos por um elemento de ligação que permite a leitura de outras faces - independentes dos rostos com "nariz alargado". Esta dupla leitura é semelhante àquela que se observa nas urnas de tipo Joanes Pintado da cultura Marajoara, onde diversos rostos - que compartilham os mesmos elementos - podem ser reconhecidos quando se gira a peça.

Na variante "b", não existe o tema clássico do campo superior; o topo da tanga é ocupado por uma linha em zigue-zague. Os dois rostos estão espelhados no sentido vertical em vez de estarem dispostos em simetria de translação. Em duas destas tangas e dois fragmento, os olhos espiralados, em vez de serem pequenos, dispostos na parte alta dos rostos e inscritos num quadrado, tornam-se muito grandes e se localizam nos ângulos da peça. O espaço entre estes dois grandes losangos laterais permite vislumbrar a silhueta de um corpo humano, cuja cabeça é figurada por um dos elementos em $\perp$.

Uma tanga parece apresentar uma estrutura semelhante àquela deste grupo, embora o "nariz" seja menos alargado e representado por uma cobra. (Fig. 13).

\section{Grupo das cabeças com nariz de cobra}

Quinze peças inteiras e dois fragmentos destacam-se por apresentar grandes cabeças triangulares de cobra (duas ou quatro, dependendo da tanga) que fazem às vezes de nariz. De fato, elas compartilham muitas características (inclusive olhos em volutas) com o grupo do "nariz alargado", a cabeça de cobra substituindo o elemento em forma de $\perp$. Em três peças (duas
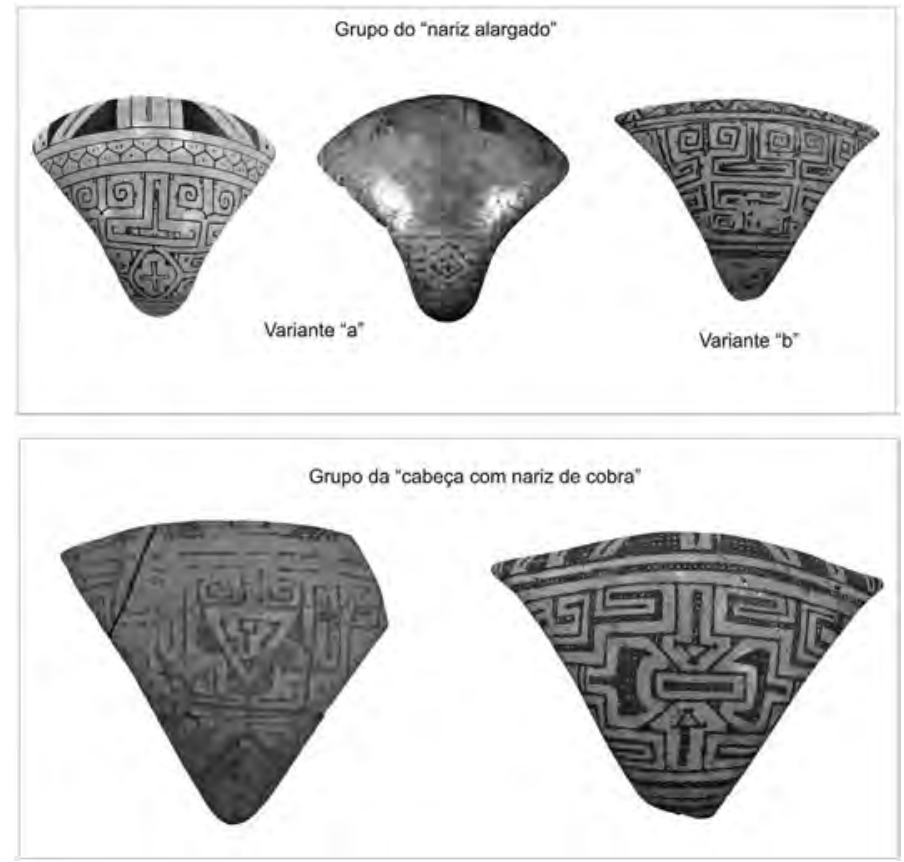

Fig. 13. Tipologia: supergrupo "B". 
delas, tão parecidas entre si que somente podem ser diferenciadas pelo seu registro superior), quatro cabeças reptilianas juntam-se no centro do rosto para circunscrever a boca. Em outros dois exemplares, o corpo das serpentes circunda o rosto, enquanto as cabeças sobem no meio dele para figurar o nariz. Nos demais artefatos, a cabeça de cobra também figura o nariz, porém cada uma de forma original. Nota-se, numa tanga, que o zigue-zague do registro médio determina triângulos com elementos internos que, eles mesmos, parecem aludir a uma cabeça ofídica.

O campo superior das peças deste grupo pode tanto apresentar elementos chapados quanto hachurados. O campo médio nunca mostra ampulhetas; o zigue-zague apresenta fórmulas variadas; o campo inferior também. Mesmo a estrutura do campo principal apresenta grande variabilidade; apenas o sub-grupo formado por três peças segue um padrão estrito (com mesma forma de olho, boca etc.).

Consideramos que os dois grupos anteriores (nariz em $\perp$ e nariz de cobra) formam, eles também, um supergrupo (“B”).

\section{Grupo com decoração tripartida}

São dezesseis peças, inclusive todas aquelas de forma 3. Apresentam uma morfologia geral mais arredondada que as demais (mesmo quando entram na categoría 1). O campo superior é muito largo; nunca apresenta elementos quadrangulares, mas triângulos particularmente estreitos e pontudos, sempre pintados com tinta chapada. O tema "ampulheta" é característico do segundo registro (aparece até na única peça que apresenta sigue-zague, entre as dobras do mesmo). Este segundo registro é normalmente muito largo e migra para a faixa central da peça. Volutas elaboradas com ganchos e cujas linhas costumam ser reforçadas por pastilhas de tinta adornam as extremidades ou os interstícios entre os elementos em forma de X.

Em razão da situação central do registro "médio", o registro principal migra para a parte inferior da peça, e as tangas deste grupo não apresentam as costumeiras linhas horizontais que marcam o registro inferior nas outras categorias. Em razão da frequente má preserva- ção das peças tripartidas, fica difícil identificar o tema decorativo do registro inferior em alguns exemplares, mas trata-se geralmente da evocação de um ou dois corpos humanos de formato retangular e membros dobrados, definidos pelo espaço entre polígonos desenhados (quadriláteros ou hexágonos). Diminutos rostos pentagonais podem também ser reconhecidos neste campo.

Pastilhas de tinta substituem as costumeiras “aspas” de reforço de linha. Várias destas tangas apresentam uma tinta muito mais espessa que aquela utilizada nas demais categorías decorativas. Mesmo assim, os desenhos destas peças costumam ser bastante alterados e a cor da tinta esmaecida - como se os pigmentos fossem particularmente frágeis.

\section{Grupo da boca dentuda}

Cinco peças, todas incompletas, apresentam uma face cuja boca, largamente aberta, apresenta dentes triangulares enquanto o nariz é representado por um largo retângulo completamente pintado. Este nariz está sempre ligado por um traço curto vertical à última das linhas que formam o registro médio. Nos maiores fragmentos, que apresentam o registro superior, este tem seus elementos quadrangulares e reticulados. Isto, além do fato de o registro "médio" estar ocupado por simples linhas paralelas, sugere que o suporte seja de forma 2.

\section{Grupo com diagonais dominantes}

Este grupo reúne peças bastante diferentes umas das outras, que não apresentam uma figuração de rosto e cuja estrutura é caracterizada pela obliquidade. Em quase todas aparece o registro superior clássico, mas, abaixo deste, o campo decorativo é unificado. Quatro destas tangas têm a forma 2 , sendo duas delas muito parecidas entre si, utilizando os mesmos elementos escalonados - diferenciam-se apenas na forma de simetria utilizada. Numa quarta peça, o tema da ampulheta, tratado de forma original, invade o campo principal enquanto na quinta, são losangos com cruz central que monopolizam a cena. Duas formosas tangas apresentam três alinhamentos de elementos poligonais cujo 
encaixe por meio de linhas diagonais provoca um efeito muito original dentro do universo estudado. (Fig. 14)

\section{Tangas não classificadas em grupos}

Quase um terço das peças com o campo principal legível não se insere nos grupos que propomos. Todas elas, no entanto, compartilham o código geral que tentamos desvendar: organização tetrapartida, elementos canônicos dos registros superior, médio e inferior. $\mathrm{O}$ rosto aparece sempre no campo principal, porém existe neste registro uma variabilidade que expressa um grau de liberdade maior para os(as) pintores(as). Mesmo assim, diversas tangas apresentam entre si semelhanças estruturais ou temáticas suficientes para sugerir a existência de outros grupos, que novos achados poderão eventualmente validar, caso o número de exemplares característicos aumente.

Por exemplo, duas tangas de forma 1, apresentam uma dissimetria dinâmica no zigue-zague do registro médio quebrado, onde o zigue-zague é tratado também de forma não canônica. $\mathrm{O}$ campo principal de uma peça apresenta uma compartimentação vertical com simetria de translação, sem que haja sugestão de um rosto. Infelizmente, o registro principal de outra peça quebrada não pode ser reconstituído de forma satisfatória, porém a parte visível é parecida.
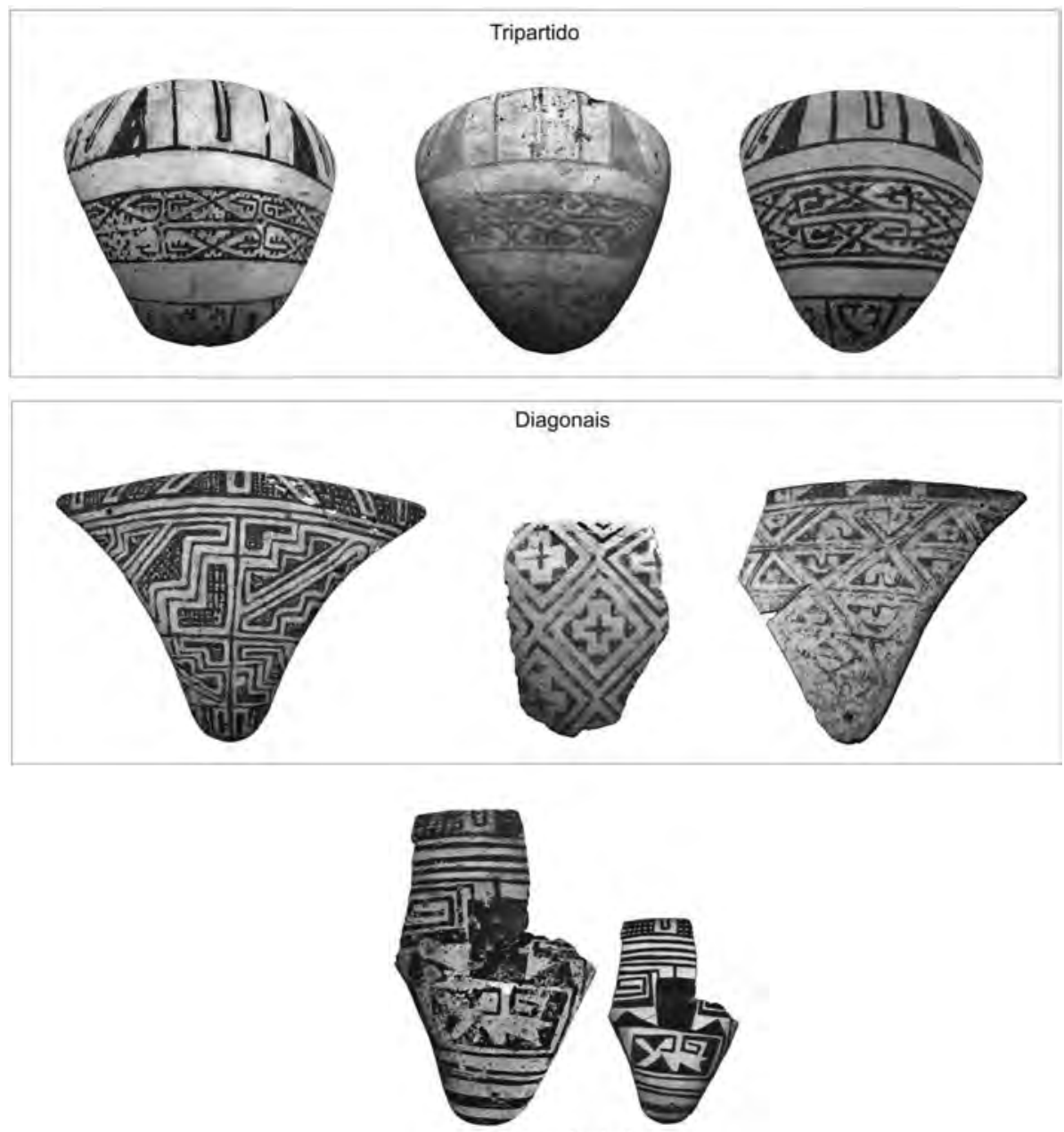

Boca dentuda

Fig. 14. Tipologia (3). 
Quatro tangas também formam um conjunto homogêneo, no qual o elemento central é muito discreto, privilegiando-se dois compartimentos laterais retangulares em forma de "portas" decoradas.

Três tangas propõem um modelo muito específico, no qual três quadrados de tamanhos semelhantes, todos marcados por uma cruz, representam os olhos e a boca. O nariz e as sobrancelhas, por sua vez, são representados por uma forma que sugere um membro dobrado tridigitado. $\mathrm{O}$ registro inferior de duas destas tangas apresenta um zigue-zague (repetindo o tema do seu registro médio) - uma exclusividade destas peças.

\section{As peças "gêmeas"}

Alguns exemplares são tão parecidos entre si que parecem não apenas apontar regras compartilhadas, mas reproduzir um mesmo modelo com variantes apenas de detalhe mínimo. Alguns dos casos mais evidentes encontram-se no grupo das peças "imbricadas", nas quais apenas um detalhe varia entre duas peças (seja a forma da boca: retângulo ou losango), seja a posição das antenas/patas anteriores da figura biomorfa (abertas ou fechadas), seja a "ampulheta” (com elementos vazios ou preenchidos por tinta) etc.. As tangas com decoração diagonalizada, com representações de quatro cobras, ou de rosto com boca e olhos quadrados fornecem também bons exemplos. Outras duas peças se distinguem apenas pela orientação de um pequeno elemento, que representa o "olho" das faces.

Estas semelhanças tanto podem expressar a existência de "pares" de objetos necessários para certas cerimônias, quanto a repetição de um modelo por uma mesma pintora - ou um membro do seu "ateliê". De fato, levando em conta a falta de informações sobre a origem de muitos exemplares, não se pode sequer descartar a priori a existência de falsificações recentes a partir de um modelo antigo.

\section{Tangas e recipientes pintados}

Pode-se indagar se a decoração das tangas obedece às mesmas regras encontradas em reci- pientes cerâmicos: temas e fórmulas decorativas. Não pretendemos dedicar mais de algumas linhas a este ponto. Inicialmente, pode-se frisar a ausência dos relevos (incisões e excisões associadas ou não à pintura) comuns entre as vasilhas decoradas. Esta diferença, no entanto, pode-se justificar pela pouca espessura das tangas e sua forma de uso. Para serem bem visiveis, incisões teriam de ser muito profundas, fragilizando as peças que são pouco espessas. A ausência de gravuras deve refletir, portanto, uma razão técnica e não uma exigência ideológica.

Quanto aos temas zoomorfos, são de identificação particularmente delicada nas tangas em razão da sua forte estilização.

Duas figuras frequentemente representadas são comuns às tangas e às vasilhas - particularmente, os sauros (sejam eles lagartos ou jacarés) e as cobras. As representações que para nós lembram "insetos", com antenas bem destacadas também ocorrem tanto em vasilhas quanto em tangas. A. Roosevelt, por exemplo (1991, fig. $1.18,-\mathrm{d})$, reproduz uma figura que só pode ser interpretada como uma borboleta com antenas espiraladas e asas representadas por cobras enroladas. A mesma figura que identificamos como "barata" ocupa uma posição central num prato exposto no Museu do Forte em Belém.

Outros temas presentes nas vasilhas não se encontram nas tangas. Por exemplo, a figura da coruja, tal como é representada nas urnas Joanes Pintado; apenas um fragmento evoca para nós esta ave, porém de forma totalmente diferente. É possivel, no entanto, que os grandes blocos quadrangulares ou losângicos, que formam os "olhos" dos rostos no campo principal das tangas, tenham sido uma forma de lembrar o tamanho desses órgãos neste animal noturno. Neste caso, a coruja estaria onipresente, porém de forma totalmente diferente daquela encontrada na maioria das urnas. $\mathrm{O}$ mesmo ocorre com o escorpião - tema destacado em algumas cerâmicas (por exemplo, no casco de representações de tartaruga); sobretudo, como mostrou Magalis (1975), um desenho esquemático deste animal é muito utilizado em estatuetas e nas urnas (do tipo 2 de Barreto (2009) para representar o globo ocular. Ora, este artrópode parece totalmente ausente das tangas - apesar de um pequeno 
elemento quadrangular com dois ou quatro apêndices que ocorre para preencher espaços vazios em algumas peças lembrar vagamente este tema. (Fig. 15)
Reproduções de felinos, de veados, de grandes roedores, de outras aves afora a coruja em geral, de sirênios e de peixes estão ausentes da decoração - tanto de vasilhas

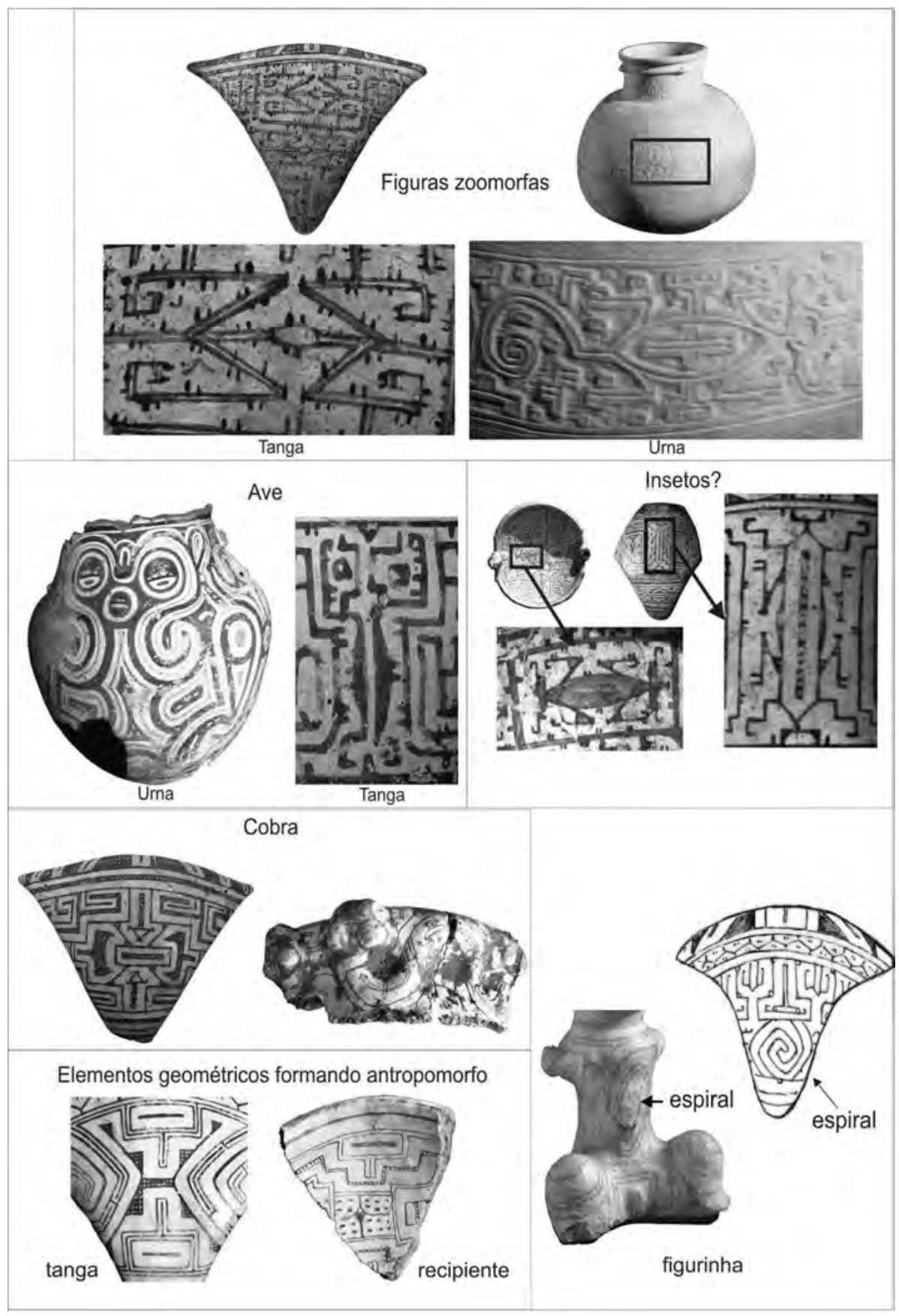

Fig. 15. Tangas, figurinhas e vasilhas: elementos comuns. 
e modelagens quanto das tangas. Mesmo considerando que o desenho de uma peça poderia a rigor ser considerado felino e que os olhos aproximadamente "pisciformes" de certos rostos possam aludir a animais aquáticos. Finalmente, nenhuma figura animal parece estar representada exclusivamente nas tangas. Estes objetos, portanto, integram parte do bestiário geral marajoara (cobra, sauro e insetos) predominante nas outras categorias de artefatos em cerâmica, do qual se excluem, no entanto, a tartaruga, a coruja e o escorpião. Talvez esses últimos estejam ligados mais especificamente à morte, enquanto a cobra (parecida com o cordão umbilical, enrolada como a espiral representada no ventre das estatuetas femininas marajoaras) seria ligada à vida.

A maior diferença entre a decoração pintada das vasilhas e aquela das tangas talvez seja o fato de que não se utilizou a cor preta nas últimas. Com efeito, as superfícies coloridas que contrastam com os traços lineares vermelhos são geralmente ressaltadas em preto nos pratos e nas urnas, enquanto são também vermelhas (muitas vezes, hachuradas) nas tangas. A presença de desenhos por linhas duplas com tinta clara intersticial encontra-se em ambos os casos. Esta oposição, provavelmente expresse uma distinção entre o sentido simbólico das cores; é tentador imaginar o vermelho mais ligado com a juventude e a vida e a cor escura com a morte; mas, neste caso, como explicar o engobo vermelho das tangas encontradas em sepultamentos?

Os elementos decorativos e a estruturação do espaço nas tangas apresentam também similitudes com aqueles das vasilhas, apesar da forma radicalmente diferente dos suportes. A divisão do espaço em campos horizontais, comum na cerâmica globular de qualquer cultura, é mantida no espaço triangular das tangas. A inserção de conjuntos significativos em espaços quadrangulares, já notada por C. Barreto (2009); a simetria ao mesmo tempo por espelhamento e translação; os jogos de kennings; os elementos de reforço de linhas e de preenchimento dos espaços vazios etc. são os mesmos.

\section{Possíveis elementos de diferenciação entre sítios e regiões}

É de se lamentar que muitas tangas encontradas nas coleções não tenham origem precisa conhecida. Sabe-se que tangas ou fragmentos não foram achados em todos os sítios - mesmo entre aqueles que foram sondados pelos arqueólogos. Entre os tesos mencionados encontram-se Bacuri Alto (Ryden, apud Meggers \& Evans 1957), dois dos tesos de Camutins (sítios J. 14 e J 15 - Meggers \& Evans ibidem; Hart 1885), Fortaleza (Farabee 1915, apud Meggers \& Evans op. cit.), Teso dos Bichos (Steere, apud Meggers \& Evans op. cit.; Roosevelt 1991), Laranjeiras e Matinados (Holridge 1939, apud Meggers \& Evans op. cit.); Teso do Severino (Mordini, Derby, Ferreira Penna 1879; Lange 1914 apud Meggers \& Evans op. cit.); Pacoval (Hartt, 1876; Lange, 1914). Parte dessas peças pode ser identificada na bibliografia e através dos catálogos de museus.

A única coleção proveniente de escavação que permita esboçar uma abordagem quantitativa é aquela reunida por B. Meggers e C. Evans (1957). Nela, a maioria dos 110 fragmentos (equivalentes a pelo menos 40 peças, portanto) vem de peças monocromas, na proporção de cerca de três a quatro peças vermelhas para uma pintada (respectivamente 83 e 27 exemplares). Nas mesmas escavações os pesquisadores encontraram, associadas a urnas funerárias (seja no interior, seja a proximidade imediata), sete tangas - das quais duas, com desenhos. Caso estes achados sejam representativos, peças decoradas e engobadas ocorreriam na mesma proporção de $1 / 3$ a $1 / 4$ tanto em contexto funerário quanto em ambiente supostamente doméstico - contrariamente à opinião vigente. Steere, por sua vez, afirma que algumas urnas do Teso dos Bichos continham belas tangas "beautifully polished and ornamented”; Hilbert (1952, citado por Meggers \& Evans 1957) retirou seis tangas de dois aterros de Camutins "mostly red slipped" - o que significa que um ou dois exemplares eram pintados sobre engobo branco. O. Derby retirou duas tangas de uma urna, sendo pelo menos uma delas decorada. 
Não sabemos qual é a porcentagem de urnas marajoara que continha tangas; se ambos os sexos fossem enterrados nos tesos e todas as mulheres fossem acompanhadas por este artefato, cerca da metade dos enterramentos adultos deveria apresentar o objeto. Infelizmente, raros são os casos de identificação de restos ósseos. Voltando à pesquisa de Meggers e Evans, nota-se que dos quinze conjuntos funerários escavados em Camutins nos tesos J 14 e J 15, quatro apresentaram tangas. Caso esta amostra seja representativa e alguns sepultamentos sejam de crianças, isto seria condizente com a possibilidade de que a maioria das mulheres levaria uma proteção pubiana para o outro mundo.

Para avaliar a possibilidade de certos elementos decorativos serem específicos de algum sítio ou conjunto de sítios podemos comparar as cinco tangas e alguns fragmentos decorados encontrados em Camutins (teso J. 15) com as 13 tangas e um fragmento provenientes de Pacoval, e com as quatro tangas e fragmentos do Teso do Severino.

No teso J. 15 de Camutins, o registro superior (tema "genitalia") é, sobretudo, formado por elementos cheios (triangulares ou trapezoidais); apenas duas peças os apresentam hachurado. Em Pacoval, tanto pode apresentar elementos cheios (geralmente triangulares) quanto faltar por completo (em pelo menos três peças), não havendo nenhum caso de elemento hachurado no registro superior. Quanto ao Teso do Severino, Mordini já tinha observado nele a ausência deste registro.

Quando se observa o registro médio, verifica-se em Camutins (J. 15) a preponderância do zigue-zague (10/12 - com diversas variantes de realização) no registro médio - embora duas peças apresentem o tema da ampulheta e duas peças do grupo Camutins o tenham marcado apenas por linhas paralelas. Em Pacoval, as ampulhetas e o zige-zague aparecem equilibrados (quatro ocorrências cada um), faltando este registro em três peças.

O campo principal nas peças de Camutins (teso J 15) apresenta, sobretudo, a organização típica do supergrupo "Camutins" /imbricados", com peças de nariz formado por lagartos e olhos pisciformes. Nota-se também a presença de uma peça de "nariz alargado", uma peça com "nariz de cobra” e outra, com estrutura oblíqua. Em Pacoval, não há peças típicas do grupo "Camutins", a única tanga aparentada a esta categoria evidencia uma estrutura absolutamente original, e o que nos parecem representações de cobras bicéfalas (tema que encontramos em duas peças proto-tupiguarani encontradas no Rio Grande do Norte e que demonstram certo parentesco estilístico com a arte marajoara). A figura do lagarto não ocorre nas peças identificadas como provenientes de Pacoval.

Em compensação, o grupo "imbricado" é representado por três exemplares neste sítio, onde se encontram também um exemplo de "nariz alargado", dois com "nariz de cobra" e uma peça com estrutura oblíqua. As demais tangas de Pacoval fogem dos grupos que definimos talvez sejam representativos de categorias típicas do leste da ilha, até agora pouco representadas nas coleções. Com efeito, elas formam pares com tangas com decoração parecida. As tangas do Teso do Severino, por sua vez, incluem uma peça com desenho de "nariz de cobra" e outra, com o "nariz alargado"-porém tratados estilisticamente de forma original. A figura 105, por sua vez, sugere a silhueta de um corpo - possivelmente antropomorfo - o que não escapou à observação de Mordini.

Nota-se que nenhum desses sítios proporcionou decoração tripartida ou rostos de "boca dentuda” - sugerindo a existência de outro(s) sítio(s) ou conjuntos regionais com pintura diferenciada. As peças tripartidas encontram-se na coleção MAE/BS e no Museu de Cachoeira do Arari; segundo C. Barreto, as peças que compõem a primeira seriam provenientes de três fazendas situadas ao longo do rio Anajás - provavelmente a jusante dos sítios de Camutins e Monte Carmelo, onde formam um grupo sul-ocidental de tesos. Quanto às tangas de boca dentada, encontradas apenas na coleção da UFSC e reunidas por Tom Wild, seriam oriundas de uma única região, que estamos tentando ainda determinar.

\section{Conclusões e divagações várias}

Verificamos, portanto, que as diferenças morfológicas não se limitam a uma oposição 
entre duas categorias - uma delas, pintada e a outra, apenas engobada - embora esta especialização possa ter existido em determinados sítios. Existem três morfologias características com algumas fórmulas decorativas exclusivas ou preferenciais de uma das três. Por outro lado, mostramos a importância do motivo "ampulhetas" ao lado do zigue-zague no segundo registro e da diferenciação entre as várias formas de tratar estes motivos do friso superior. De fato, eles não nos parecem remeter a desenhos de peles de cobra, embora a sinuosidade do zigue-zague possa aludir a um corpo reptiliano. Em contrapartida, as alusões a seres vivos são bem mais claras no registro principal. Acreditamos ter conseguido contribuir ao entendimento da temática que caracteriza as tangas marajoaras, particularmente com a identificação do rosto como elemento central - e, provavelmente, principal - da quase totalidade das tangas pintadas. Este rosto é formado da combinação de vários elementos canônicos, alguns dos quais são zoomorfos. Entre estes, os mais facilmente identificáveis são cobras e lagartos; outros seres, embora apresentem por vezes quatro patas, são provavelmente insetos. De fato, as fórmulas decorativas são pouco numerosas, embora a criatividade das pintoras se expresse através dos detalhes da sua execução.

\section{Implicações simbólicas da temática}

Como interpretar os temas figurativos que parecem predominar? Não há dúvida que cobra e sauros sejam personagens essenciais em todas as mitologias amazônicas atuais e pré-históricas, e ambos são bem representados nas vasilhas marajoara. Por oposição, frisamos a pouca visibilidade nas tangas - se não a total ausência - das representações de ave (talvez, no entanto, figurada num único fragmento), do escorpião e da onça. Mesmo raro no ambiente alagadiço da planície oriental de $\mathrm{Ma}$ rajó, o grande carnívoro não está ausente da ilha e devia ser bem conhecido dos moradores dos tesos. Voláteis, por sua vez, não faltam em nenhuma parte da ilha. O bestiário das tangas não privilegia, portanto, a dupla de animais que os arqueólogos gostam de imaginar associada ao xamanismo ou às linhagens aristocráticas do Baixo e Médio Amazonas (o que não significa que estas instituições não tenham existido durante a Fase Marajoara). Talvez cobra e lagarto, com seu corpo filiforme, sejam uma alegoria do cordão umbilical. Afinal, o ventre feminino (supostamente representado no registro superior) é o receptáculo do qual os humanos (representados pela cara do registro principal) surgem, com intermediação do cordão (presente na forma da cobra no registro médio e talvez representado pela espiral em certas faces). Freudianos não deixariam de sugerir um simbolismo sexual para a cobra. Notemos a ausência também do peixe-boi, de peixes e de roedores no vocabulário gráfico. Ir além destas observações significaria entrar em conjecturas impossíveis de serem testadas atualmente, divagações incapazes de esconderem nossa impossibilidade de acessar o significado do código marajoara. Em compensação, está ao nosso alcance o reconhecimento dos elementos que o constituem e a estrutura da sua articulação.

\section{Implicações das categorias de decoração}

Um dos nossos propósitos principais, a determinação de estilos cronológicos e/ou regionais, foi frustrado pela falta de elementos para avaliar sua idade. Os primeiros coletores (Hartt 1876; Derby 1879; Netto 1885) notaram que, em Pacoval, as cerâmicas que apresentariam a decoração de maior qualidade encontrar-se-iam exclusivamente nos níveis mais antigos (Kern 2008); mesmo assim, não falavam especificamente das tangas. B. Meggers e C. Evans resgataram esta observação, que reforçava sua hipótese da importação seguida de degenerescência da cultura marajoara. A hipótese de um rápido declínio da arte gráfica não se tendo sustentado e na falta de qualquer datação de tangas achadas em escavações, não há como saber se as observações feitas no século XIX aplicam-se às peças de vestuário; nem se correspondem aos acasos de uma única escavação, ou a uma realidade pré-histórica no sítio de Pacoval. 
Não foi apenas a falta de quadro cronológico a prejudicar a pesquisa, mas também a desastrosa ausência de identificação do local de origem para cerca de $80 \%$ das peças. Desta forma, a tipologia que esboçamos, e que poderia ter sido reforçada ou modificada por eventuais coincidências na distribuição geográfica, teve de se apoiar essencialmente em semelhanças formais. Assim agrupamos os artefatos em função de semelhanças maiores ou menores nos temas, na disposição dos mesmos no espaço gráfico, ou das técnicas gráficas utilizadas. $\mathrm{O}$ que poderiam indicar estes agrupamentos? As tangas "parecidas" entre si poderiam indicar uma mesma autoria (neste caso, haveria artesãos especializados em sua fabricação e/ou decoração?). Também poderiam expressar divisões sociais (hipótese levantada por D. Schaan) dentro de uma mesma localidade; digamos, por exemplo, que ostentar um "nariz-lagarto" seja privilégio das moças de uma metade social (numa estrutura social dual), de um clã, ou aos membros de uma categoria hierárquica, enquanto o "nariz com narinas largas" seria a marca de outra metade ou categoria social. Finalmente, os grupos ou variantes dos mesmos poderiam remeter a espaços geográficos politicamente diferenciados. Para que se possam avaliar estas diversas possibilidades, seria necessário verificar vários pontos. Em primeiro, se vários grupos temáticos e/ou estilísticos teriam coexistido num mesmo local (sítio ou território) e no mesmo período, ou se eles seriam mutuamente exclusivos, pelo menos em determinados sítios. Talvez isto seja possível dentro de alguns anos, quando novas técnicas permitirem identificar com precisão a procedência das argilas, e datar a queima das tangas a partir de técnicas não destrutivas. Por enquanto, tivemos que nos contentar em considerar apenas duas dezenas de tangas não datadas, provenientes de apenas três sítios - o que restringe muito a credibilidade das nossas observações. Vimos que estas sugerem de fato a existência de algumas diferenças entre as peças de Camutins (talvez representantes de uma fácies ocidental) e de Pacoval (seria representativo de uma fácies oriental?), sendo difícil caracterizar a produção do Teso de Severino, pelo reduzido número de peças. Talvez dois grupos, não representados entre as peças com certeza atribuídas a esses três sítios, sejam específicos de outros tesos.

\section{As tangas e a sociedade marajoara}

Vimos que a construção da grande maioria das decorações é submetida a uma rigorosa simetria espelhada, que combina com a organização da peça ao redor de uma representação de face humana. Algumas peças, no entanto, fogem de forma consciente e elaborada a esta simetria óbvia, privilegiando a obliquidade. É tentador, lembrando-se do texto clássico de C. Lévi-Strauss (1958) sobre as pinturas corporais Kadíweu, interpretar esta situação como a expressão de uma sociedade ainda fundamentalmente igualitária, mas na qual já apontaria a tentação da hierarquização. Não cairemos, no entanto, nesta tentação, que justificaria um discurso tão vazio quanto instigante - mesmo porque a maioria das tangas apresenta uma decoração absolutamente simétrica - o que não implica, também, negar uma possibilidade de hierarquização na sociedade marajoara. Contra-exemplos seriam numerosos para mostrar a vaidade de tais associações. Quanto à complexidade dos desenhos e sua qualidade gráfica, usá-las para afirmar que implicam uma especialização dos seus autores, elemento que os neo-evolucionistas gostam de associar com uma "complexidade emergente" e um "estagio" cacical. Caçadores-coletores aborígenes da Austrália desde a pré-história (através das pinturas rupestres do norte do país) até hoje (através das suas pinturas em casca) demonstram amplamente a maestria que qualquer indivíduo bem dotado e experiente pode alcançar nas artes da sua sociedade. Aliás, quem hoje negaria a complexidade das sociedades de caçadores aborígenes, quando avaliadas por padrões que não são exclusivamente os nossos? Assim, os belos desenhos das tangas marajoaras não nos informam sobre as contradições internas da sociedade que as produziu. Podemos, no entanto, desvendar aos poucos seu código gráfico: foi esta tarefa que procuramos iniciar. Somente depois de avançar mais nesta via e depois de realizadas muitas escavações extensas em novos sítios, tornar-se-á possível estudar modas temporais, regionalismos, rituais e possivelmente, perceber segmentos sociais dentro do mundo marajoara. Para tanto, é necessário que seja assegurada uma efetiva proteção dos sítios, vários dos quais vêm 
sendo destruídos pelo pisoteio das manadas de búfalo e pelas escavações ilegais. As delicadas tangas atualmente disponíveis para estudo, em sua maioria retiradas dos tesos sem contextualização antes de chegar às instituições ou aos colecionadores, perderam a maior parte do seu poder para guiar nossos passos no caminho do redescobrimento da sociedade marajoara.

\section{Agradecimentos}

Agradecemos aos colegas e responsáveis que nos abriram suas coleções e aos técnicos que nos ajudaram: V. Guapindaia, Regina Farias, Edna Moutinho Amauri Matos e Jorge Mardock Neto, do MPEG; M.B. Florenzano, V. Wesolowski, Luis Carlos Borges e Ana Carolina Vieira, do MAE-USP. D. Schaan (UFPA), que nos forneceu a ilustração de uma das suas apresentações; A. Delpuech (Musée du Quai Branly, Paris), que proporcionou uma cópia dos artigos de Mordini. A. de Tugny (UFMG), com quem discutimos a morfologia das tangas. Rosângela de Oliveira, para a revisão do texto. T. Fossari e Vanilde Guizoni, do Museu Universitário da UFSC. D. Schaan, que nos ofereceu generosamente cópia da sua documentação. A Diretoria dos Museus do Arari (Maria José da Conceição Gama; Sandra Solange Souza; José E. Rabelo de Souza; Otaci Gemaque), bem como a Claudia e Paulo Câmara. Aos Diretores e funcionários dos Museus das Gemas (Ana Cristina ResqueMeirelles) e do Forte (Samuel Sostenes; Dauseane Ferras) de Belém. A Dona Inez, viúva do famoso oleiro de Icoaraci, Mestre Cardoso.

PROUS, A.; LIMA, A.P. Ceramic Pubic Covers from Marajo Island, Brazil. R. Museu Arq. Etn., São Paulo, n. 21, p. 231-263, 2011.

Abstract: Ceramic pubic covers (tangas) are characteristics of Marajoara Phase, at the mouth of the Amazon river. We have studied more than 140 painted tangas and 84 plain ones. Rules for drawing, spacial organization have been perused. We show that the central figure is a highly schematic face representation, made using a kenning system. The morphology of the tangas, the pictural organization and the thematic elements are correlated, so it is possible to propose seven typological categories. Their significance (chronological, regional or social) is discussed, though the lack of datings and scarcity of accurate information on the origin of the artifacts prevent us to reach satisfactory results. We have also studied use wear on the archaeological covers. Our collaborators have produced ceramic tanga replicas and experimented their use in several ways.

Keywords: Ceramic pubic covers - Marajoara Phase - Amazonian archaeology - Painted ceramics.

\section{Referências bibliográficas}

BARATA, F.

1952 Arqueologia. (Coleção: As Artes plásticas no Brasil). Rio de Janeiro: Edições de Ouro, 228 p.
BARRETO, C.

2009 Meios místicos de reprodução social: arte e estilo na cerâmica funerária da Amazônia Antiga. Tese de Doutorado, São Paulo, USP. 2334+ 69 p. 
COSTA, A.

1939 Migrações e Cultura indígena. Rio de Janeiro: Companhia Editora Nacional. $273 \mathrm{p}$.

DERBY, O.A.

1879 The artificial Mounds of the Island of Marajo, Brazil. American Naturalist, 13 (4): 224-229 (apud Mattos 1938 e Meggers \& Evans 1957).

FERREIRA PENNA, D.

1879 Apontamentos sobre os cerâmios do Pará. Archivos do Museu Nacional, Rio de Janeiro, 2: 47-67.

FREITAS, R.P. DE

2009 Fluorescência de fragmentos de tanga. Dissertação de Mestrado, Rio de Janeiro,UFRJ, 78 p.

HARTT, C.F.

1871 The Ancient Indian Pottery of Marajo. The American Naturalist, 5: 259-271.

1876 Nota sobre algumas tangas de barro cosido dos antigos indígenas da ilha de Marajó. Archivos do Museu Nacional, Rio de Janeiro, 1: 21-25.

\section{HERANCุA}

1984 A expressão visual do brasileiro antes da influência do europeu. São Paulo: Dow.152 p.

HOLRIDGE, D.

1939 Feudal Island. New York: Harcourt, Brace and Company.

KERN, D.P.M.

2008 Da vida para a História: a redescoberta de Charles Frederick Hartt na era Vargas. IX Encontro Estadual de História, ANPUH-RS, Porto Alegre: 1-10.

LANGE, A.

1914 The Lower Amazon. New York: G.P. Putnam's Sons (apud Meggers \& Evans 1957).

LÉVI-STRAUSS, C.

1958 L'Anthropologie Structurale. Paris: Plon ed. MATTOS, A.

1938 Pré-história brasileira. São Paulo/Rio de Janeiro: Cia Editora Nacional. 307 p.

MEGGERS, B.; EVANS, C.

1957 Archeology at the Mouth of the Amazon. Bureau of American Ethnology, 167. 663 p.

MORDINI, A.

1929 I "couvre-sexe" precolombiani in argilla dell'isola di Marajó. Archivio per l'Antropologia e la Etnologia, Firenze, 59: 41-46.

1934 Des cultures précolombiennes du bas Amazone et leur développement artisti- que. Congrès Internacional des Américanistes, Actes, Session 24, Hamburg: 61-65.

NETTO, L.

1885 Investigações sobre a arqueologia brasileira. Archivos do Museu Nacional, Rio de Janeiro, 6: 257-554. Texto consultado na versão reproduzida por B. Ramos 1930 .

1890 Sur les antiquités céramiques de l'île de Marajó. Congrès International des Américanistes, Berlin: 201-206 (não consultado).

PALMATARY, $\mathrm{H}$.

1950 The Pottery of Marajo Island, Brazil, Trans. of American Phil. Society, 39 (3): 260368.

PROUS, A.

2007 Arte pré-histórica Brasileira. Belo Horizonte: C/Arte.

RAMOS, A.

1930 Inscrições e tradições da América Prehistórica, vol. 1. Rio de Janeiro: Imprensa Nacional, $514 \mathrm{p}$.

RIBEIRO, D.

1961 Arte dos Índios Kaduveu. Cultura, Rio de Janeiro, 4: 147-10.

ROOSEVELT, A.C.

1991 Moundbuilders of the Amazone. New York: Academic Press. 495p.

SCHAAN, D.P.

2001 Into the labyrinth of Marajoara Pottery. In: Ewan, Mc; Barreto, C.; Neves, E.G. (Eds.) Unknown Amazon. London, The Bristish Museum Press:108 - 133.

2003 As ceramistas, seu pote e sua tanga: identidade e papéis sociais em um cacicado marajoara. Revista de Arqueologia, 16: 34 45.

2007 A Arte das Sociedades de Tradição Oral. Habitus, Universidade Católica de Goiás, Goiânia, 5 (1): 99- 117.

SIMÕES, M.F.

1967 Resultados preliminares de uma prospecção arqueológica na região dos rios Goiapí e Câmara (ilha de Marajó). Simpósio sobre a biota Amazônica, Belém, Atas (2): 207-224.

SKIBO, J.

1992 Pottery Function: A use-alteration perspective. New York \& London: Plenum Press.

STEERE, J.

1927 The Archaeology of the Amazon. Univ. of Michigan Official Publ., 29 (9) part 2:20-26 (apud Meggers \& Evans 1957).

STEWARD, J.; MÉTRAUX, A.

1948 Tribes of the Peruvian and Ecuadorian 
Montaña. Handbook of South American Indians, Bureau of American Ethnology Bulletin, 143 (3): 535-656.

TESSMANN, G.

1928 Menschen ohne Gott: Ein Besuch bei den Indianern des Ucayali. Stuttgart: Strecker \& Schröder Eds. (apud Steward \& Métraux 1948: The Panoan Tribes of Eastern Peru).

TORRES, H.A.

1929 Ceramica de Marajó. Rio de Janeiro: Imprensa Nacional. 15 p.

TROUFFLARD, J.

2010 Testemunhos funerários da Ilha do Marajó no Museu Dr. Santos Rocha e no Museu Nacional de Etnologia. Interpretação arqueológica. Dissertação de Mestrado, Lisboa, Universidade Nova de Lisboa. 280 p.

Fotografias consultadas na INTERNET:

Pre Columbian Marajoara Brazil Ceremonial Tanga (site de venda de peças)

Barreto, C. Simbolismo sexual da Antiga Amazônia INTERNET.

Isto é Independente

Site do Museu Nacional, Rio de Janeiro

Recebido para publicação em 2 de dezembro de 2011. 